\title{
Health status and portfolio choice: Is their relationship economically relevant?
}

\author{
Silvia Bressan ${ }^{\mathrm{a}}$, Noemi Pace ${ }^{\mathrm{b}}$, Loriana Pelizzon ${ }^{\mathrm{b}, \mathrm{c}, *}$ \\ a Vienna Graduate School of Finance, Austria \\ ${ }^{\mathrm{b}} \mathrm{Ca}$ ' Foscari University of Venice, Italy \\ c SAFE-Goethe University Frankfurt, Germany
}

\section{A R T I C L E I N F O}

\section{Article history:}

Received 17 December 2013

Received in revised form 8 January 2014

Accepted 10 January 2014

Available online 31 January 2014

\section{JEL classifications:}

D8

E2

Keywords:

Household portfolios

Health status

\begin{abstract}
A B S T R A C T
Recent empirical work on individual portfolio choice focuses on the role of the individual's health in making financial decisions. The key idea is that, through precautionary saving or reducing investors' time horizon, health issues make people choose safer financial portfolios. This paper questions the empirical relevance of the link between health and portfolio choice, measured as stockownership and overall fraction of risky securities held. We handle with caution the findings from previous papers and ask whether data from the first wave of the Survey of Health, Aging and Retirement in Europe (SHARE) are able to clarify some of our doubts. We find that only poor self-reported health negatively impacts the portfolio choice, while other health measures (chronic conditions, limitations in daily activities of life, mental health) are irrelevant for investment decisions.
\end{abstract}

(c) 2014 Elsevier Inc. All rights reserved.

\section{Introduction}

The Modern Portfolio Theory (MPT) postulates that risk averse investors choose their investment portfolios in order to maximize their expected return for a predetermined level of risk. The optimal portfolio chosen by the investor will depend on the shape of her utility function. In recent years, the basic assumptions of MPT have been widely challenged by the behavioral finance approach, which has thrown new insight onto investment decision theory. Behavioral finance evaluates risk mostly based on laboratory experiments and surveys or questionnaire instruments, and concentrates on beliefs, attitudes and risk perception in particular circumstances. Among other factors, an individual's health status has recently gained attention as a potential determinant of risk perception and security holdings. Recent literature has developed a portfolio choice theory which includes the presence of "background" risk, defined as an uninsurable component of individuals' income risk which decreases additional financial risks (Gollier, 2001; Guiso, Jappelli, \& Terlizzese, 1996; Guiso \& Paiella, 2001). Some researchers have put effort into demonstrating how health can be regarded as a form of background risk, and provide empirical results on how financial investment choices change with health conditions. The most frequent finding is that, a sudden health issue or poor health conditions tend to shift resources towards safer types of financial investments, with disaffection from the participation to the equity

\footnotetext{
* Corresponding author at: University Ca' Foscari of Venice, Department of Economics, Cannaregio 87, 30121 Venezia, Italy. Tel.: + 390412349164

E-mail address: pelizzon@unive.it (L. Pelizzon).
}

market and from the holding of risky securities. Papers support with various arguments the way in which health affects portfolio choice. Some sustain that there is a precautionary saving purpose behind the health effect, to the extent that the expected future medical expenditures subtract resources from financial investments (among others, see Atella, Brunetti, \& Maestas, 2012; Berkowitz \& Qiu, 2006; Goldman \& Maestas, 2007; Gollier \& Pratt, 1996; Heaton \& Lucas, 2000; Pang \& Warshawsky, 2010; Pratt \& Zeckhauser, 1987). Others consider the interplay between health and other circumstances which affect the life span horizon, such as aging (Coile \& Milligan, 2009) or bequest motives (Feinstein \& Lin, 2006). Finally, some papers propose models where health enters as a direct argument of the investor utility function, and the marginal utility of consumption is found to vary with health (among others, see Cardak \& Wilkins, 2009; Edwards, 2008; Finkelstein, Luttmer, \& Notowidigdo, 2008; Love \& Smith, 2010; Rosen \& Wu, 2004). Evidently, the relationship occurring between health status and portfolio choice is actively discussed in the literature, and the standpoint of researchers in the field is extremely heterogeneous.

With this work we wish to take part in this debate, and our focus is on deeply understanding whether there is a relevant link between health status and portfolio choice. More specifically, we contribute to the previous literature surveying the individual health condition in a more extensive way. Since the health dimension is characterized by various different facets, our analysis aims at establishing the relationship occurring with portfolio decisions from different proxies of health, where each proxy should reflect a specific health dimension (subjective, objective, and mental health). We use data contained in the first wave of the Survey of Health, Ageing and Retirement in Europe (SHARE), which 
paints a picture of the lives of Europeans aged 50 and over from 11 countries. We concentrate on the decision of households on their stockholding, and on the relative share of their portfolio which is invested into risky assets. Our empirical models relate these two choices on the household health condition, while controlling for a large number of individual and household characteristics, as the household composition and various socio-economic features. We mainly test the most common channels that the literature so far has suggested as drivers for the impact from health on investments, and that we have mentioned few rows above. In particular, we check whether the implication from health on portfolio choice is imputable to precautionary saving and/or risk aversion changes. Despite we cannot rule out if one channel is more effective than the other, our results suggest that, a significant path from health on portfolio choice is only associable to a measure of subjective health. More specifically, people self-reporting a negative health condition are found to be less likely in owning some stocks and are holding fewer risky assets. If we instead measure the physical health status of the same respondents (counting the number of limitations in daily life activities or the number of chronic diseases), or measure their psychological feelings (through a depression scale), than it does not hold any more that being worse in health has significant affections on investments. Our results show that, the prediction of a negative health risk on financial choices highly depends on the notion of health we refer to, since we showed that different health measures might yield inconsistent results. The rest of the paper is organized as follows: Section 2 reviews the most relevant contributions to the literature which has surveyed the effect of health status on portfolio choice; Sections 3 and 4 present the data and describe in more detail the variables of interest; Section 5 reports the econometric results; Section 6 provides the conclusions and some discussion of the results, comparing them with previous contributions in the literature.

\section{The effect of health status on portfolio choice}

There is abundant evidence of an association between economic measures, such as income and wealth, and a variety of variables which are linked to the state of health of individuals. Indeed, several studies confirm the existence of a link between the two spheres. However, there is still no consensus on the nature and the direction of this relationship. On the one hand, changes in socio-economic status may lead to worse health status. On the other hand, also changes of the health status may have an impact on the individuals' income and wealth: a poor health status, limiting the ability to work and increasing medical costs, could restrict opportunities for individual income and accumulated wealth. According to Palumbo (1999), the expectation of substantial future medical expenses reduces, as a precautionary measure, the current and future consumption. Moreover, if the marginal utility of consumption decreases with worsening health conditions, individuals will be inclined to consume more when they are healthy compared to periods in which they are sick, and save more when the probability of a worsening of their health status increases. Closely related to this is the question of the impact of a poor health status on life expectancy: in life-cycle models, the mortality risk induces a transfer of future consumption towards the present. Smith (1999) finds that under the risk of future health problems, subjects might be induced to reduce the transfer of wealth to heirs, rather than decrease theirconsumption. According to this logic, current status of health and probability to leave an inheritance are strongly correlated.

In the following paragraphs, we focus on the recent literature that studies the relationship between health status and portfolio choices. Previous contributions in the empirical literature suggest different channels through which health might affect financial decisions, i.e. precautionary saving motive, direct effect of marginal utility of consumption, and the perception of the life span and planning horizon.

\subsection{First channel: precautionary saving motive}

The fear of potential health shocks can lead to higher medical spending which absorbs the financial wealth of the investor. In this view, health expenditures is a type of undiversifiable background risk that induces precautionary saving and prompts safer portfolios (among all: Atella et al., 2012; Berkowitz \& Qiu, 2006; Goldman \& Maestas, 2007; Gollier \& Pratt, 1996; Heaton \& Lucas, 2000; Pang \& Warshawsky, 2010; Pratt \& Zeckhauser, 1987). Our work attempts to complement the works by Atella et al. (2012) and Guiso et al. (1996). The former uses the same data source as our current research (the Survey of Health, Aging and Retirement in Europe, SHARE) to show how health risk affects the portfolio choice only of those investors living in countries with a less protective healthcare system. Their result highlights the role of national healthcare systems in reducing the overall background risk faced by households and, consequently, in dampening the precautionary saving purpose. Guiso et al. (1996) use data from the Survey of Household Income and Wealth, and focuses on the investigation of the relationship between stockholding choices and different household characteristics. The authors argue that, among other factors, future medical expenses are a common source of risk, as they find that households headed by individuals who spent more days sick tend to hold safer financial portfolios, even after controlling for many other individual characteristics.

\subsection{Second channel: direct effect on the marginal utility of consumption}

Health status could have an impact on financial decisions through its direct effect on the marginal utility of consumption. Edwards (2010) explores the implications for portfolio choice of a special type of statedependent utility function, which includes consumption and health. The author proves that, if the cross partial derivative of utility with respect to consumption and health is negative, then investors who perceive their health status as poor will hedge by holding safer financial portfolios. Finkelstein et al. (2008) use seven waves of panel data on older individuals from the Health and Retirement Study (HRS) and estimate how individual adverse health events affect a proxy for utility, comparing the effects across people of different income levels. They find robust evidence of the fact that deteriorations in health are associated to a statistically significant decline in the marginal utility of consumption. Cardak and Wilkins (2009) use data from the Household Income and Labour Dynamics in Australia (HILDA) survey to investigate the determinants of the portfolio allocation of Australian households. Their results suggest that the share of risky assets held in financial portfolios is significantly and negatively affected by poor health status. They retain that poor health conditions reduce risky asset holdings via its effects on measured risk and time preferences. In their analysis, households that consider themselves financially risk averse have a much lower risky asset ratio. Using data from the Health and Retirement Study (HRS), Rosen and Wu (2004) find that a fair or poor health status reduces the probability of holding risky assets as well as the portfolio shares held in those assets. Possible explanations for this outcome are explored using variables for health insurance, bequest motive and planning horizon, though, according to their analyses, none of these latter ways seems to be the channel through which health status explicates an effect on portfolio composition.

\subsection{Third channel: life span and planning horizon}

A third potential channel is through life span and time horizon. All things equal, advancing age leaves less time remaining before death, which may be a reason to invest more safely.

Using data from the Health and Retirement Survey (HRS), Coile and Milligan (2009) focus on the influence of aging and health shocks on households' portfolio choice, and find that health shocks explain part of the changes in households' portfolios over time. Feinstein and Lin 
(2006) propose a model for elderly asset management and present results based on simulations from the model. Among their findings, authors show that elderly agents in poor health and exposed to greater health expenditure risk, place a slightly lower proportion of their assets in stocks than individuals in good health. A related issue is the bequest motive. Hurd (2002) claims that, while for young people this is quite a remote event, for aged people a bequest motive can extend the time horizon, reducing the effects of mortality risk.

\section{Data}

In this study, we use data contained in the first wave of SHARE, the Survey of Health, Ageing and Retirement in Europe; its main focus is to provide information on the lives of Europeans aged 50 and over, collecting data in 11 countries from Scandinavia to the Mediterranean. The survey covers 19,548 households and 28,517 individuals on a wide range of topics, encompassing health, socioeconomic status, financial transfers, and intensity of social interaction. For our research, particular attention goes to variables expressing wealth and health conditions. From these, we manage to construct indicators for portfolio choice and to relate them to different health proxies. Some of the questions refer to the household while others are posed to the single respondent. In this case, since our analysis mainly focuses on the households, we combine individual information and take the household average.

\section{Measuring health status}

SHARE devotes a section of the questionnaire to measuring health status. Empirically, health status is an intrinsically unobservable variable. A formal definition of health status unavoidably involves a number of facets suggesting an exploration of different variables available in SHARE to take into account the multiple dimensions among which the notion of health develops. As a first approximation, we can divide the information of health status into objective and subjective. Concerning the first category, SHARE provides the number of limitations in activities of daily living and the number of chronic diseases. ${ }^{1}$

Regarding the second category, SHARE provides information on selfperceived health status (SPHEU), reported on a 5-point scale ( $1=$ Excellent, 2 = Very Good, 3 = Good, $4=$ Fair, 5 = Poor). As Rosen and Wu (2004) and Atella et al. (2012) point out, many contributions in the literature document the validity of self-reported health status. The last relevant health variable included in SHARE is mental health. This is measured by a depression scale variable (EURO-D) which runs from 0 to 12 , counting whether the individual reported having problems during the last month from a list of negative feelings, including depression, pessimism, guilt, irritability and tearfulness. Fig. 1 provides the sample distributions of the four indicators of health status. Descriptive statistics (see Table 1 ) show that only $9.5 \%$ of the sample have some limitations with activities of daily living (the dummy variable ADL2 denotes whether the respondent suffers at least one limitation) and the average number is 0.183 (st.dev. 0.624). More than $41 \%$ of the sample declare two or more chronic diseases (the dummy variable chronic2 denotes whether the respondent suffers at least one chronic disease) and the average number of chronic diseases is 1.513 (st. dev. 1.308). More than $37 \%$ of the sample perceive a subjective health status as being fair or poor, and the average point-scale is 2.301 (st. dev. 0.838). Only $6 \%$ of the sample has a depression scale higher than 7 , and the average scale is 2.339 (st. dev. 2.086). Table 2 also shows a high level of heterogeneity across countries.

\footnotetext{
1 The former includes difficulty in dressing, walking, bathing, eating, getting in or out of bed and using the toilet (ADL). The latter includes heart attack, high blood pressure, high blood cholesterol, diabetes, asthma, arthritis, osteoporosis, Parkinson's and cancer (chronic).
}

\section{Stockownership and risky investment}

During the investment process, an individual makes the crucial decision whether or not to spend some of his resources in financial securities traded in organized exchange markets. SHARE respondents are asked about the amount of money they hold in the following financial products: bank accounts, bonds, stocks, individual retirement accounts, contractual savings for housing, whole and term life insurance. As in Christelis, Jappelli, and Padula (2010), we distinguish between direct stockownership and total stockownership, which includes stocks held directly plus stocks held through mutual funds and investment accounts.

In our sample we capture these features of the portfolio choice by two dichotomous variables. The variable for direct stockownership assumes value one if the household has invested any positive amount in stocks. The variable for total stockownership assumes value one if the household has invested into stocks, or mutual funds, or individual investment accounts, assuming these two latter financial products have a certain share invested as well into stocks. Table 3 provides some descriptive statistics on direct and total stockholding. Thirteen percent of our sample invests directly in stocks, while more than twice that (26.7\%) holds stocks either directly or through mutual funds and individual retirement accounts. This table also shows a high level of heterogeneity in stockholding across European countries.

While structuring the investment portfolio and in accordance with main insight provided by portfolio theory, the individual typically diversifies among different classes of financial assets. For this reason, in our sample we define the "risky" fraction of the investment portfolio of our households as the sum of stocks, mutual funds and individual retirement accounts over the total gross financial wealth.

\section{Unconditional relationship between stock market participation and health status}

Our purpose is to investigate the relationship linking stockholding and risky investment to health conditions, identified by four variables (disabilities in daily life activities (ADL), chronic conditions, selfperceived health status (SPHEU) and mental health). To get a first glance of the type of connection, in Figs. 2 and 3 we plot stockholding and risky investments (respectively) over the four proxies of health conditions. In general, objective health seems to have a negative relationship with both stockholding and the relative amount of risky investments, though the path is not continuous and some discontinuities are observable for a large number of limitations or chronic diseases (see Fig. 2a and b). The effect of SPHEU is clearer. The dependent variable in Fig. 2c decreases continuously, suggesting that, as long as the individual reports a poorer view of himself, he tends to leave the equity market and drive resource towards other different and "safer" form of investments. Fig. 3c clearly shows that while people reporting excellent health conditions hold $20 \%$ of their resources in risky assets, individuals in poor health status reduce this proportion to below $5 \%$. The effect has the same direction when we consider the mental health indicator EUROD, and in Figs. 2d and 3d we see how the more symptoms of depression are declared, than the more are discouraged riskier investment choices.

\section{Conditional relationship between stock market participation and health status}

An unconditional analysis may hide the role of other explanatory variables affecting stockholding. For this reason, we estimate a regression model for each of our three dependent variables (direct stockholding, total stockholding, share of risky investment), in which we consider stockholding or the share of risky investment on the left hand side and health status plus a set of control variables on the right hand side. In particular we include the following control variables: age 

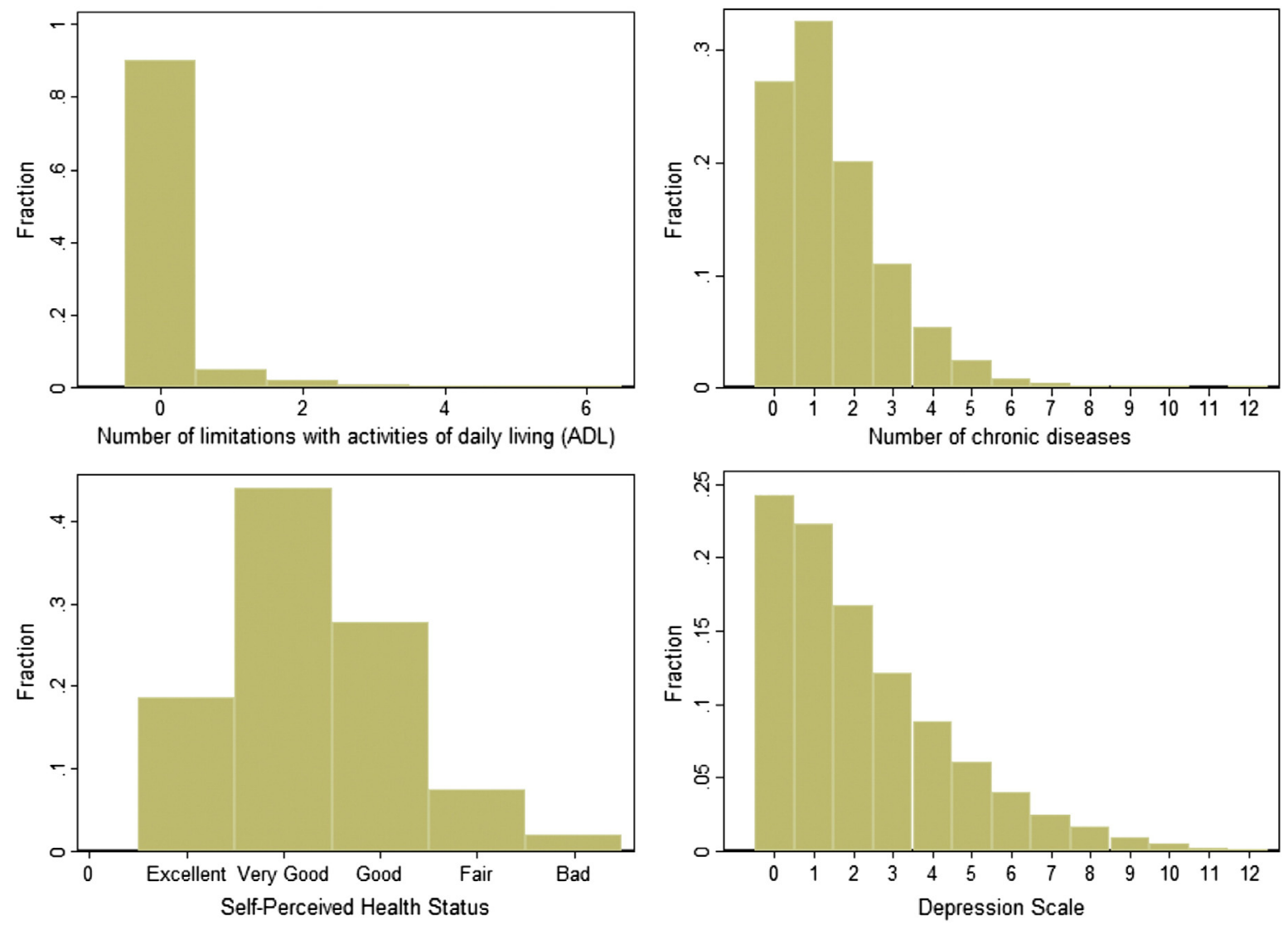

Fig. 1. Sample distributions of the health status indicators.

and its square, education level, number of household's members, employment characteristics, indicators of household resources (gross financial income, real assets and household disposable income), a variable for social activities, a set of indicators for cognitive abilities, and the expectations of leaving an inheritance and country dummies. The four proxies of health status (number of limitation in daily life activities, number of chronic conditions, self-perceived health status and mental health) are considered separately.

To model the stock holding decision more formally, we assume that households compare the utility gain from owning stocks with the entry cost. We express the net utility as:

$y_{h}^{*}=X_{h}^{\prime} \delta+\varepsilon_{h}$

where $h$ is the household index and $X_{h}$ are the observable variables affecting the utility gain from owning stocks. Household $h$ owns stocks if $y_{h}^{*} \geq 0$, which implies that the probability of observing stockownership is $\Phi\left(X^{\prime}{ }_{h} \delta\right)$. If the unobservable factors are normally distributed, we can use a probit model for direct and total stock market participation estimated with standard maximum likelihood methods. The probit model allows interpreting the estimated marginal effects of the independent variables as their impact on the probability that the household holds some stocks in its portfolio (directly, or, also via "indirect" ownership of stocks). For the share of risky investment we use a censored normal regression model (or Tobit model) to take into account the fact that an optimizing behavior often leads to corner solutions for some nontrivial fraction of the population. Indeed, for some households the optimal share of risky investment coincides with the corner solution of zero investment (see Miniaci \& Weber, 2002; Rosen \& Wu, 2004 for a review and summary of various econometric issues in estimating portfolio choice models). With the Tobit model we estimate how a one unit change in the independent variables affects uncensored observations. In the set $X_{\boldsymbol{h}}$ of observable variables we include age and its square, a scaled variable for the education level, the number of household members, a dummy for self-employment, indicators of household resources (gross financial income, real assets and household disposable income), a variable for social activities, a set of indicators for cognitive abilities, and the expectations of leaving an inheritance. To these regressors we add a variable expressive of the health status. Given the complexity of the definition of health status, data enable us to investigate the effect of health on portfolio choice among four different dimensions. In each specification the health proxy is changed and the regression is run anew, according to which health explanatory variable is considered. The first two health proxies (number of limitation in activities of daily life - ADL - and number of chronic diseases) are regarded as a measure of the individual objective health. The third variable is a proxy of a more subjective and personal dimension of health, the health condition as reported by the person interviewed, according to his or her feeling and judgment (SPHEU). The fourth variable is the indicator of the mental health of the individual (EUROD), and takes into account reported negative psychological feelings. The four health proxies are then considered simultaneously and, given the low correlation among them and the large sample size, we do not worry about multicollinearity.

\section{Econometric results}

This section presents, first of all, the baseline results. We then discuss the results obtained from a deeper analysis conducted to disentangle the channels of health risk transmission. 
Table 1

Descriptive statistics of health conditions.

\begin{tabular}{|c|c|c|c|c|c|}
\hline Variable & Mean & Std. dev. & Min & Max & Obs. \\
\hline Number of limitations in activities of daily life (ADL) & 0.183 & 0.624 & 0 & 6 & 18,402 \\
\hline ADL2 & 0.095 & 0.266 & 0 & 1 & 18,402 \\
\hline Number of chronic diseases (chronic) & 1.513 & 1.308 & 0 & 10 & 18,402 \\
\hline Chronic2 & 0.411 & 0.444 & 0 & 1 & 18,402 \\
\hline Self-reported health (SPHEU) & 2.301 & 0.838 & 1 & 5 & 18,402 \\
\hline SPHEU2 & 0.374 & 0.439 & 0 & 1 & 18,402 \\
\hline Depression (EUROD) & 2.339 & 2.086 & 0 & 12 & 18,402 \\
\hline EUROD2 & 0.061 & 0.221 & 0 & 1 & 18,402 \\
\hline
\end{tabular}

The variables are taken at their household mean value.

Table 2

Descriptive statistics of health conditions by country.

\begin{tabular}{|c|c|c|c|c|c|c|c|}
\hline & Austria & Germany & Sweden & & Netherland & Spain & Italy \\
\hline Number of limitations in activities of daily life (ADL) & 0.171 & 0.171 & 0.160 & & 0.151 & 0.262 & 0.219 \\
\hline Number of chronic diseases (chronic) & 1.266 & 1.461 & 1.507 & & 1.290 & 1.822 & 1.702 \\
\hline Self-reported health (SPHEU) & 2. 332 & 2.471 & 2.169 & & 2.195 & 2.577 & 2.565 \\
\hline Depression (EUROD) & 2.002 & 1.939 & 2.021 & & 2.050 & 3.155 & 2.914 \\
\hline \multirow[t]{2}{*}{ Observations } & 1371 & 1927 & 2066 & & 1851 & 1630 & 1703 \\
\hline & France & Denmark & & Greece & \multicolumn{2}{|r|}{ Switzerland } & Belgium \\
\hline Number of limitations in activities of daily life (ADL) & 0.187 & 0.200 & & 0.149 & \multicolumn{2}{|r|}{0.098} & 0.204 \\
\hline Number of chronic diseases (chronic) & 1.559 & 1.603 & & 1.411 & \multicolumn{2}{|r|}{1.036} & 1.656 \\
\hline Self-reported health (SPHEU) & 2.328 & 2.173 & & 2.180 & \multicolumn{2}{|r|}{1.894} & 2.205 \\
\hline Depression (EUROD) & 2.856 & 1.872 & & 2.244 & \multicolumn{2}{|r|}{1.953} & 2.373 \\
\hline Observations & 1880 & 1117 & & 1818 & \multicolumn{2}{|r|}{649} & 2390 \\
\hline
\end{tabular}

The variables are taken at their household mean value. Standard errors in parentheses.

\section{Baseline results}

As mentioned above, we build a regression model for each of our three dependent variables (direct stockholding, total stockholding, fraction of risky investment). Tables 4 and 5 provide the results for the effect of health status on direct stockholding and total stockholding, respectively. Table 6 contains the outcome of the regression estimated for the fraction of risky investment. The whole set of health variables has a negative effect on both stock market participation decision as well as on the percentage of risk carried by the portfolio. Between the two proxies of objective health status (ADL and chronic), statistically significant effects are found only for the indicator of chronic diseases with respect to direct stockholding. The results become highly significant when the health indicator is allowed to coincide with the self-reported health conditions. Tables 4, 5 and 6 show that SPHEU has got a significantly negative effect on all the dependent variables; bad self-perceived health status would lead individuals to reduce both their equity investment and their financial risk-taking. In absolute terms, the marginal effect of SPHEU is always much larger than the marginal effect of the other proxies. We estimate a marginal effect of SPHEU of -0.013 (st. err. 0.004) and -0.033 (st. err. 0.006) for the direct and total stockholding respectively, and a coefficient of -0.064 (st. err. 0.012 ) for risky investment. The marginal effects of chronic diseases are -0.005 (st. err. 0.002), -0.006 (st. err. 0.004 ) for direct and total stockholding respectively, and the coefficient is -0.011 (st. err. 0.007) for risky investment, while for EUROD the effect is negative and statistically significant only for the fraction of risky investment (coefficient -0.013 , st. err. 0.004). To provide a broader overview of the negative impact of health risk on the portfolio decision, we include the four health proxies simultaneously in the explanatory set of the estimated specifications. As seen in Table 7, SPHEU remains significantly negative across specifications, while the other three proxies of health status are not statistically relevant.

Table 3

Descriptive statistics of stockholding and risky investment by country.

\begin{tabular}{|c|c|c|c|c|c|c|}
\hline & Whole sample & Austria & Germany & Sweden & Netherland & Spain \\
\hline Direct stockholding & $\begin{array}{l}0.175 \\
(0.380)\end{array}$ & $\begin{array}{l}0.055 \\
(0.229)\end{array}$ & $\begin{array}{l}0.148 \\
(0.355)\end{array}$ & $\begin{array}{l}0.422 \\
(0.494)\end{array}$ & $\begin{array}{l}0.190 \\
(0.392)\end{array}$ & $\begin{array}{l}0.071 \\
(0.257)\end{array}$ \\
\hline Total stockholding & $\begin{array}{l}0.327 \\
(0.469)\end{array}$ & $\begin{array}{l}0.104 \\
(0.305)\end{array}$ & $\begin{array}{l}0.282 \\
(0.450)\end{array}$ & $\begin{array}{l}0.751 \\
(0.433)\end{array}$ & $\begin{array}{l}0.265 \\
(0.442)\end{array}$ & $\begin{array}{l}0.142 \\
(0.349)\end{array}$ \\
\hline Risky investment & $\begin{array}{l}0.158 \\
(0.288)\end{array}$ & $\begin{array}{l}0.037 \\
(0.145)\end{array}$ & $\begin{array}{l}0.099 \\
(0.217)\end{array}$ & $\begin{array}{l}0.438 \\
(0.354)\end{array}$ & $\begin{array}{l}0.097 \\
(0.223)\end{array}$ & $\begin{array}{l}0.078 \\
(0.221)\end{array}$ \\
\hline Observations & 18,402 & 1371 & 1927 & 2066 & 1851 & 1630 \\
\hline & Italy & France & Denmark & Greece & Switzerland & Belgium \\
\hline Direct stockholding & $\begin{array}{l}0.056 \\
(0.231)\end{array}$ & $\begin{array}{l}0.163 \\
(0.370)\end{array}$ & $\begin{array}{l}0.341 \\
(0.474)\end{array}$ & $\begin{array}{l}0.063 \\
(0.243)\end{array}$ & $\begin{array}{l}0.270 \\
(0.444)\end{array}$ & $\begin{array}{l}0.190 \\
(0.392)\end{array}$ \\
\hline Total stockholding & $\begin{array}{l}0.140 \\
(0.347)\end{array}$ & $\begin{array}{l}0.434 \\
(0.496)\end{array}$ & $\begin{array}{l}0.568 \\
(0.496)\end{array}$ & $\begin{array}{l}0.109 \\
(0.312)\end{array}$ & $\begin{array}{l}0.359 \\
(0.480)\end{array}$ & $\begin{array}{l}0.395 \\
(0.489)\end{array}$ \\
\hline Risky investment & $\begin{array}{l}0.070 \\
(0.209)\end{array}$ & $\begin{array}{l}0.222 \\
(0.323)\end{array}$ & $\begin{array}{l}0.250 \\
(0.324)\end{array}$ & $\begin{array}{l}0.045 \\
(0.158)\end{array}$ & $\begin{array}{l}0.158 \\
(0.286)\end{array}$ & $\begin{array}{l}0.190 \\
(0.309)\end{array}$ \\
\hline Observations & 1703 & 1880 & 1117 & 1818 & 649 & 2390 \\
\hline
\end{tabular}

The variables are taken at their household mean value. Standard errors in parentheses. 

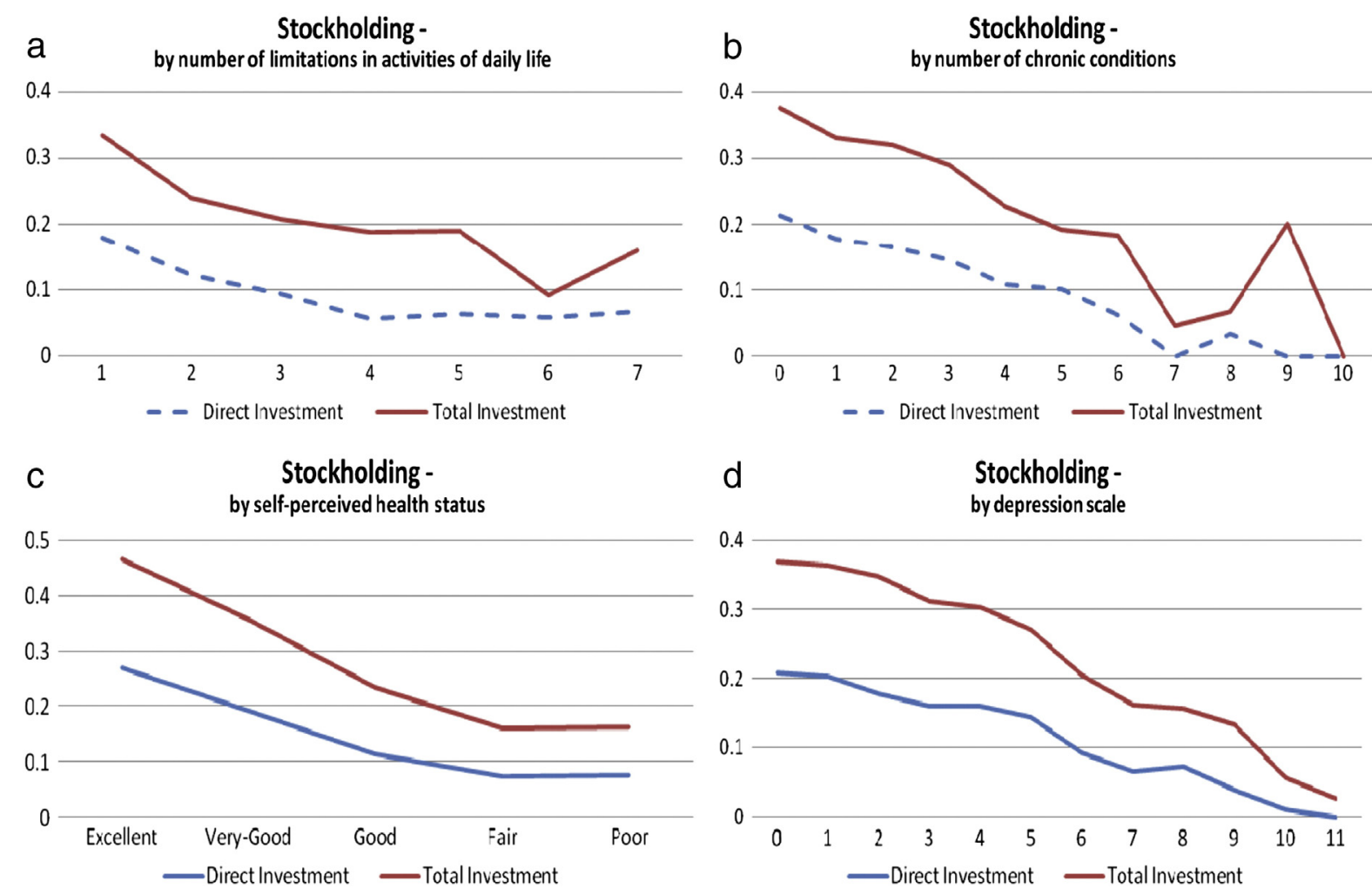

Fig. 2. Direct and total stock market participation by health status.

\section{Disentangling health risk transmission}

In this section we try to disentangle the different channels through which health risk may have an effect on investment decisions, thus we wish to provide information on the reasons which bring people in bad health to disaffect from the equity market and to decrease the level of financial risk undertaken. A deeper understanding of the channels of health risk transmission is important because it might involve relevant policy implications. Indeed, it would help to introduce incentives specifically designed to increase the stock market participation. As mentioned in

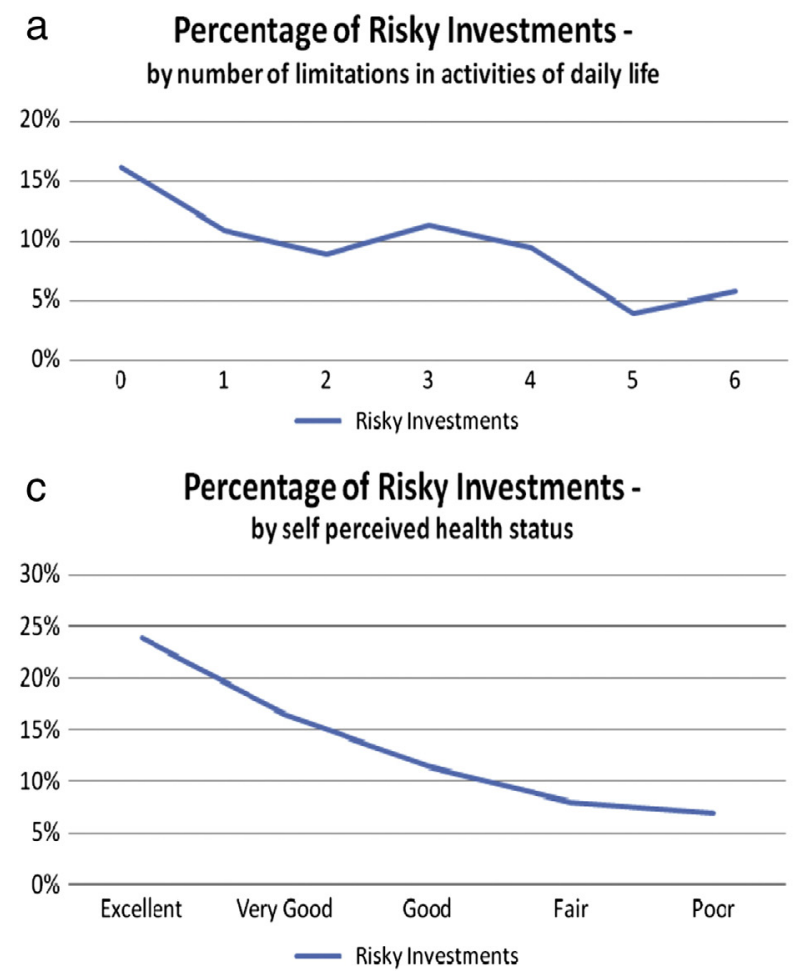

\section{b Percentage of Risky Investments - by number of chronic conditions}

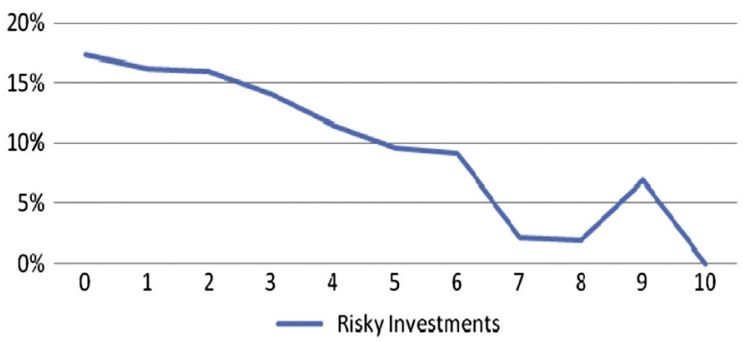

\section{d Percentage of Risky Investments - by depression scale}

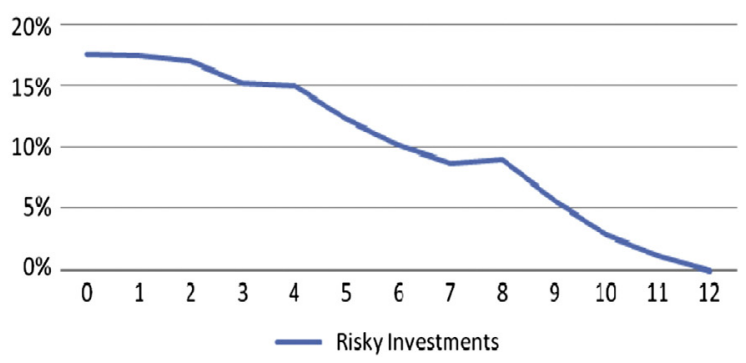

Fig. 3. Percentage of risky investment by health status. 
Table 4

Probit regressions for direct stockholding - alternative proxies for health status.

\begin{tabular}{|c|c|c|c|c|}
\hline Direct stockholding & $\begin{array}{l}(1) \\
d y / d x\end{array}$ & $\begin{array}{l}(2) \\
\mathrm{dy} / \mathrm{dx}\end{array}$ & $\begin{array}{l}(3) \\
\mathrm{dy} / \mathrm{dx}\end{array}$ & $\begin{array}{l}(4) \\
\mathrm{dy} / \mathrm{dx}\end{array}$ \\
\hline Number of limitations in activities of daily life (ADL) & $\begin{array}{l}-0.004 \\
(0.005)\end{array}$ & & & \\
\hline Number of chronic diseases (chronic) & & $\begin{array}{l}-0.005^{\text {*** }} \\
(0.002)\end{array}$ & & \\
\hline Self-reported health (SPHEU) & & & $\begin{array}{l}-0.013^{* * *} \\
(0.004)\end{array}$ & \\
\hline Depression (EUROD) & & & & $\begin{array}{l}-0.002 \\
(0.001)\end{array}$ \\
\hline Age & $\begin{array}{l}0.003 \\
(0.004)\end{array}$ & $\begin{array}{l}0.003 \\
(0.004)\end{array}$ & $\begin{array}{l}0.003 \\
(0.004)\end{array}$ & $\begin{array}{l}0.003 \\
(0.004)\end{array}$ \\
\hline Age squared & $\begin{array}{l}-0.000 \\
(0.000)\end{array}$ & $\begin{array}{l}-0.000 \\
(0.000)\end{array}$ & $\begin{array}{l}-0.000 \\
(0.000)\end{array}$ & $\begin{array}{l}-0.000 \\
(0.000)\end{array}$ \\
\hline Number of household components & $\begin{array}{l}0.022^{* * *} \\
(0.005)\end{array}$ & $\begin{array}{l}0.022^{* * *} \\
(0.005)\end{array}$ & $\begin{array}{l}0.023^{* * * *} \\
(0.005)\end{array}$ & $\begin{array}{l}0.021^{\text {**** }} \\
(0.005)\end{array}$ \\
\hline Education level & $\begin{array}{l}0.022^{* * * *} \\
(0.002)\end{array}$ & $\begin{array}{l}0.022^{* * *} \\
(0.002)\end{array}$ & $\begin{array}{l}0.021^{* * *} \\
(0.002)\end{array}$ & $\begin{array}{l}0.022^{\text {**** }} \\
(0.002)\end{array}$ \\
\hline Numeracy & $\begin{array}{l}0.022^{*} * * * \\
(0.003)\end{array}$ & $\begin{array}{l}0.022^{* * * *} \\
(0.003)\end{array}$ & $\begin{array}{l}0.021^{* * * *} \\
(0.003)\end{array}$ & $\begin{array}{l}0.022^{* * * *} \\
(0.003)\end{array}$ \\
\hline Fluency & $\begin{array}{l}0.001^{* *} \\
(0.000)\end{array}$ & $\begin{array}{l}0.001^{* *} \\
(0.000)\end{array}$ & $\begin{array}{l}0.001^{* *} \\
(0.000)\end{array}$ & $\begin{array}{l}0.001^{* *} \\
(0.000)\end{array}$ \\
\hline Recall & $\begin{array}{l}0.006^{* * *} \\
(0.002)\end{array}$ & $\begin{array}{l}0.006^{* * *} \\
(0.002)\end{array}$ & $\begin{array}{l}0.005^{* * *} \\
(0.002)\end{array}$ & $\begin{array}{l}0.006^{* * *} \\
(0.002)\end{array}$ \\
\hline Employed & $\begin{array}{l}0.001 \\
(0.008)\end{array}$ & $\begin{array}{l}0.000 \\
(0.008)\end{array}$ & $\begin{array}{l}-0.001 \\
(0.008)\end{array}$ & $\begin{array}{l}0.000 \\
(0.008)\end{array}$ \\
\hline Social activities & $\begin{array}{l}0.027^{* * *} \\
(0.006)\end{array}$ & $\begin{array}{l}0.027^{* * * *} \\
(0.006)\end{array}$ & $\begin{array}{l}0.025^{* * *} \\
(0.006)\end{array}$ & $\begin{array}{l}0.026^{* * * *} \\
(0.006)\end{array}$ \\
\hline Probability of leaving an inheritance greater than 50,000 euro & $\begin{array}{l}0.001^{* * *} \\
(0.000)\end{array}$ & $\begin{array}{l}0.001^{* * *} \\
(0.000)\end{array}$ & $\begin{array}{l}0.001^{* * *} \\
(0.000)\end{array}$ & $\begin{array}{l}0.001^{\text {**** }} \\
(0.000)\end{array}$ \\
\hline Household income (in 100,000 euro) & $\begin{array}{l}0.004^{* *} \\
(0.002)\end{array}$ & $\begin{array}{l}0.004^{* *} \\
(0.002)\end{array}$ & $\begin{array}{l}0.004^{* *} \\
(0.002)\end{array}$ & $\begin{array}{l}0.004^{* *} \\
(0.002)\end{array}$ \\
\hline Real assets (in 100,000 euro) & $\begin{array}{l}0.001^{* * * *} \\
(0.000)\end{array}$ & $\begin{array}{l}0.001^{* * *} \\
(0.000)\end{array}$ & $\begin{array}{l}0.001^{* * *} \\
(0.000)\end{array}$ & $\begin{array}{l}0.001^{\text {**** }} \\
(0.000)\end{array}$ \\
\hline Household financial assets (in 100,000 euro) & $\begin{array}{l}0.028^{* * *} \\
(0.004)\end{array}$ & $\begin{array}{l}0.027^{* * *} \\
(0.004)\end{array}$ & $\begin{array}{l}0.027^{* * *} \\
(0.003)\end{array}$ & $\begin{array}{l}0.027^{* * *} \\
(0.004)\end{array}$ \\
\hline $\mathrm{R}^{2}$ & 0.222 & 0.222 & 0.223 & 0.222 \\
\hline Observations & 18,402 & 18,402 & 18,402 & 18,402 \\
\hline
\end{tabular}

Estimation is performed at household level and the variables are taken at their household mean value.

Each regression includes a complete set of country dummies.

We report the marginal effects. Standard errors are in parentheses.

Significance: ${ }^{*} 10 \%,{ }^{* *} 5 \%,{ }^{* * *} 1 \%$ confidence levels.

Section 2, previous contributions identify three main channels: precautionary saving motive, direct effect on the marginal utility of consumption (pure risk aversion), and the perception of life span. Let us start from the latter. Bad health is perceived as a factor that shortens the individual time horizon, with the consequence of setting up safer portfolios. Moreover, investors' age can affect directly portfolio allocations, independently on its effect on health, as Ameriks and Zeldes (2004) point out in their exhaustive survey. They find that the direction of the effect is far from simple, since it depends on the choice of the utility function, the correlation of income and rate of return shocks, transaction costs, the behavior of risk aversion over the lifetime, and taxes.

In our specifications, we always check for age and age squared and the results show that these variables are almost never significant, suggesting that age per se has no explanatory power on portfolio choice. All our models have been augmented by an interaction term between the health proxies and a dummy variable denoting whether the age level is above or equal to 65 (see Table 8). Again, the proxy of selfperceived health status is always statistically significant at the $1 \%$ level, and the marginal effect for the stock market participation is even slightly lower in absolute value for people aged $65+$, evidence that would suggest the idea that our results would not be importantly driven by the older fraction of the population. Another way to test this channel of health risk transmission might be taking into account the individual life expectancy. SHARE questionnaire asks respondents about their life expectancy. In particular, they are requested to declare their expected probability of living for the next ten years. Taking the complement to 1, we get a proxy for the expectation of dying within the same time horizon. The interaction of such a variable with health would measure the effect on portfolio choice of bad health conditions accompanied by an increase in the expectation of not living for more than ten years. Table 9 shows that the direction of this effect is not clear and in none of the cases significant. Health still continues to have a negative impact on investments and this effect could not be strongly addressed to the reduction in the planning horizon.

As already noticed, another important factor that may affect the perception of the length of the life span is the expectation to leave a bequest. For this reason, in all specifications we control for the bequest motive measured by the probability of leaving an inheritance larger than 50,000 euro. The results show that when taking into account the bequest motive as well, the negative relationship between stockholding and the proxies of health status still holds. Overall, the results seem to suggest that the shortening of life span is not a channel of health risk transmission.

Another potential channel for health risk transmission is identified as the "precautionary saving motive". According to this view, the threat of sustaining unexpected medical payments determines estrangement from risky securities, while holding safer portfolios should guarantee available resources for future health expenditures. To stress this idea, we use the information related to the purchase of private health insurance. If health insurance offers a buffer towards future health expenditures, then we would expect that the connection between 
Table 5

Probit regressions for total stockholding - alternative proxies for health status.

\begin{tabular}{|c|c|c|c|c|}
\hline Total stockholding & $\begin{array}{l}(1) \\
\mathrm{dy} / \mathrm{dx}\end{array}$ & $\begin{array}{l}(2) \\
\mathrm{dy} / \mathrm{dx}\end{array}$ & $\begin{array}{l}(3) \\
\mathrm{dy} / \mathrm{dx}\end{array}$ & $\begin{array}{l}(4) \\
\mathrm{dy} / \mathrm{dx}\end{array}$ \\
\hline Number of limitations in activities of daily life (ADL) & $\begin{array}{c}-0.004 \\
(0.009)\end{array}$ & & & \\
\hline Number of chronic diseases (chronic) & & $\begin{array}{l}-0.006^{*} \\
(0.004)\end{array}$ & & \\
\hline Self-reported health (SPHEU) & & & $\begin{array}{l}-0.033^{* * * *} \\
(0.006)\end{array}$ & \\
\hline Depression (EUROD) & & & & $\begin{array}{l}-0.004 \\
(0.002)\end{array}$ \\
\hline Age & $\begin{array}{l}0.013^{*} \\
(0.006)\end{array}$ & $\begin{array}{l}0.013^{* *} \\
(0.006)\end{array}$ & $\begin{array}{l}0.013^{* *} \\
(0.006)\end{array}$ & $\begin{array}{l}0.012^{*} \\
0.006\end{array}$ \\
\hline Age squared & $\begin{array}{l}-0.000^{* *} \\
(0.000)\end{array}$ & $\begin{array}{l}-0.000^{* * *} \\
(0.000)\end{array}$ & $\begin{array}{l}-0.000^{* *} \\
(0.000)\end{array}$ & $\begin{array}{l}-0.000^{* *} \\
(0.000)\end{array}$ \\
\hline Number of household components & $\begin{array}{l}0.032^{\text {**** }} \\
(0.009)\end{array}$ & $\begin{array}{l}0.031^{* * * *} \\
(0.009)\end{array}$ & $\begin{array}{l}0.033^{* * * *} \\
(0.009)\end{array}$ & $\begin{array}{l}0.031^{\text {**** }} \\
(0.009)\end{array}$ \\
\hline Education level & $\begin{array}{l}0.036^{* * *} \\
(0.004)\end{array}$ & $\begin{array}{l}0.036^{* * *} \\
(0.004)\end{array}$ & $\begin{array}{l}0.035^{* * *} \\
(0.004)\end{array}$ & $\begin{array}{l}0.036^{* * *} \\
(0.004)\end{array}$ \\
\hline Numeracy & $\begin{array}{l}0.036^{* * * *} \\
(0.006)\end{array}$ & $\begin{array}{l}0.035^{* * * *} \\
(0.006)\end{array}$ & $\begin{array}{l}0.033^{* * * *} \\
(0.006)\end{array}$ & $\begin{array}{l}0.035^{* * * *} \\
(0.006)\end{array}$ \\
\hline Fluency & $\begin{array}{l}0.003^{* * *} \\
(0.001)\end{array}$ & $\begin{array}{l}0.003^{* * *} \\
(0.001)\end{array}$ & $\begin{array}{l}0.003^{* * *} \\
(0.001)\end{array}$ & $\begin{array}{l}0.003^{* * * *} \\
(0.001)\end{array}$ \\
\hline Recall & $\begin{array}{l}0.007^{* *} \\
(0.003)\end{array}$ & $\begin{array}{l}0.007 * * \\
(0.003)\end{array}$ & $\begin{array}{l}0.006^{* *} \\
(0.003)\end{array}$ & $\begin{array}{l}0.007^{* *} \\
(0.003)\end{array}$ \\
\hline Employed & $\begin{array}{l}0.010 \\
(0.013)\end{array}$ & $\begin{array}{l}0.009 \\
(0.013)\end{array}$ & $\begin{array}{l}0.003 \\
(0.013)\end{array}$ & $\begin{array}{l}0.009 \\
(0.013)\end{array}$ \\
\hline Social activities & $\begin{array}{l}0.078^{* * *} \\
(0.012)\end{array}$ & $\begin{array}{l}0.078^{* * * *} \\
(0.012)\end{array}$ & $\begin{array}{l}0.073^{* * *} \\
(0.012)\end{array}$ & $\begin{array}{l}0.077^{* * *} \\
(0.012)\end{array}$ \\
\hline Probability of leaving an inheritance greater than 50,000 euro & $\begin{array}{l}0.001^{* * *} \\
(0.000)\end{array}$ & $\begin{array}{l}0.001^{* * *} \\
(0.000)\end{array}$ & $\begin{array}{l}0.001^{* * *} \\
(0.000)\end{array}$ & $\begin{array}{l}0.001^{* * * *} \\
(0.000)\end{array}$ \\
\hline Household income (in 100,000 euro) & $\begin{array}{l}0.008 \\
(0.006)\end{array}$ & $\begin{array}{l}0.008 \\
(0.006)\end{array}$ & $\begin{array}{l}0.008 \\
(0.006)\end{array}$ & $\begin{array}{l}0.008 \\
(0.006)\end{array}$ \\
\hline Real assets (in 100,000 euro) & $\begin{array}{l}0.002^{* * *} \\
(0.000)\end{array}$ & $\begin{array}{l}0.002^{* * *} \\
(0.000)\end{array}$ & $\begin{array}{l}0.002^{* * *} \\
(0.000)\end{array}$ & $\begin{array}{l}0.002^{* * * *} \\
(0.000)\end{array}$ \\
\hline $\begin{array}{l}\text { Household financial assets } \\
\text { (In 100,000 euro) }\end{array}$ & $\begin{array}{l}0.139^{* * *} \\
(0.009)\end{array}$ & $\begin{array}{l}0.139 * * * \\
(0.008)\end{array}$ & $\begin{array}{l}0.137^{* * *} \\
(0.008)\end{array}$ & $\begin{array}{l}0.139^{* * * *} \\
(0.009)\end{array}$ \\
\hline $\mathrm{R}^{2}$ & 0.298 & 0.298 & 0.300 & 0.298 \\
\hline Observations & 18,402 & 18,402 & 18,402 & 18,402 \\
\hline
\end{tabular}

Same as in Table 6.

portfolio choice and health is influenced by health insurance coverage. We test this hypothesis in the same way as Rosen and Wu (2004), and include in all our models a dummy variable denoting whether the individual owns any private health insurance or not. Results are reported in Table 10. Our outcome is similar to Rosen and $\mathrm{Wu}$ (2004) in two aspects: the results show $i$ ) the positive and significant marginal effect of health insurance on portfolio choice, and ii) the negative effect of health is still persisting despite we check for health insurance ownership. In order to test this issue in a more extensive way, we add in Table 11 interaction terms between the health status and private health insurance coverage. Each interaction term should capture the impact of health on the dependent variable as the respondent holds a private health insurance. Adding the interaction terms, the health insurance dummy is no more significant, whereas we observe a positive and statistically relevant coefficient as we interact the health insurance dummy with SPHEU. People who are reporting worsening health conditions are nonetheless incentivized to invest into equities, as long as they are holding a private health insurance. Although, the estimated total effect from self-perceived health remains negative on portfolio choice. Interesting results are not found for the other interactions.

If we previously focused on private health insurance coverage, we retain that, we should also consider that public health insurance could have an impact on our results. The presence of a national health system may weaken the precautionary saving intention of investors, as they could rely on public health coverage in order to face health shocks, and ultimately could employ resources for other purposes, affording to take more financial risk. Atella et al. (2012) sustain that health risk affects portfolio choices only in countries with less protective healthcare systems. We run our specifications splitting the sample in a way similar to that used in Atella et al. (2012), distinguishing between countries with a national health system with full coverage (NHS), namely Denmark, Italy, Spain and Sweden, from those countries with a national health system with partial coverage (non-NHS), namely Austria, Belgium, France, Germany, Greece, The Netherlands and Switzerland. In general, NHS countries grant full coverage for a comprehensive package of medical expenditures to face negative health events, while in non-NHS countries the public health system is not fully protective and several forms of private health insurance cover medical expenditures.

From Table 12 we deduce that SPHEU still continues to be significantly negatively estimated across both NHS countries and non-NHS countries. We also control for the ownership of private health insurance and its interactions with the four proxies of health status. This table shows that, in countries with partial coverage, the effect of SPHEU on stockholding and share of risky investment is negative and significant, and the magnitude of this effect is almost double with respect to countries characterized by a NHS with full coverage. In non-NHS countries the marginal effect from the interaction between SPHEU and the private health insurance dummy is always positive and significant, although the total effect from SPHEU on the total stockholding and the share of risky investment persists to be negative.

We note that, grouping the countries by national health system like in Atella et al. (2012) might not be properly recommendable. However, we wanted to provide results which more seriously consider country 
Table 6

Tobit regressions for risky investment - alternative proxies for health status.

\begin{tabular}{|c|c|c|c|c|}
\hline Risky Investment & (1) & $(2)$ & (3) & (4) \\
\hline Number of limitations in activities of daily life (ADL) & $\begin{array}{l}-0.013 \\
(0.017)\end{array}$ & & & \\
\hline Number of chronic diseases (chronic) & & $\begin{array}{l}-0.011 \\
(0.007)\end{array}$ & & \\
\hline Self-reported health (SPHEU) & & & $\begin{array}{l}-0.064^{* * * *} \\
(0.012)\end{array}$ & \\
\hline Depression (EUROD) & & & & $\begin{array}{l}-0.013^{* * *} \\
(0.004)\end{array}$ \\
\hline Age & $\begin{array}{l}0.013 \\
(0.011)\end{array}$ & $\begin{array}{l}0.015 \\
(0.011)\end{array}$ & $\begin{array}{l}0.014 \\
(0.011)\end{array}$ & $\begin{array}{l}0.013 \\
(0.011)\end{array}$ \\
\hline Age squared & $\begin{array}{l}-0.000^{*} \\
(0.000)\end{array}$ & $\begin{array}{l}0.000^{*} \\
(0.000)\end{array}$ & $\begin{array}{l}-0.000^{*} \\
(0.000)\end{array}$ & $\begin{array}{l}-0.000 \\
(0.000)\end{array}$ \\
\hline Number of household components & $\begin{array}{l}0.054^{* * *} \\
(0.016)\end{array}$ & $\begin{array}{l}0.053^{* * *} \\
(0.016)\end{array}$ & $\begin{array}{l}0.057^{* * * *} \\
(0.016)\end{array}$ & $\begin{array}{l}0.050^{* * * *} \\
(0.016)\end{array}$ \\
\hline Education level & $\begin{array}{l}0.076^{* * * *} \\
(0.007)\end{array}$ & $\begin{array}{l}0.076^{* * * *} \\
(0.007)\end{array}$ & $\begin{array}{l}0.073^{* * * *} \\
(0.007)\end{array}$ & $\begin{array}{l}0.075^{* * *} \\
(0.007)\end{array}$ \\
\hline Numeracy & $\begin{array}{l}0.068^{* * * *} \\
(0.010)\end{array}$ & $\begin{array}{l}0.067^{* * *} \\
(0.010)\end{array}$ & $\begin{array}{l}0.063^{* * *} \\
(0.010)\end{array}$ & $\begin{array}{l}0.065^{* * *} \\
(0.010)\end{array}$ \\
\hline Fluency & $\begin{array}{l}0.006^{* * * *} \\
(0.001)\end{array}$ & $\begin{array}{l}0.006^{* * *} \\
(0.001)\end{array}$ & $\begin{array}{l}0.006^{* * *} \\
(0.001)\end{array}$ & $\begin{array}{l}0.006^{* * *} \\
(0.001)\end{array}$ \\
\hline Recall & $\begin{array}{l}0.012^{* *} \\
(0.005)\end{array}$ & $\begin{array}{l}0.012^{* *} \\
(0.005)\end{array}$ & $\begin{array}{l}0.011^{* *} \\
(0.005)\end{array}$ & $\begin{array}{l}0.012^{* *} \\
(0.005)\end{array}$ \\
\hline Employed & $\begin{array}{l}0.018 \\
(0.024)\end{array}$ & $\begin{array}{l}0.016 \\
(0.024)\end{array}$ & $\begin{array}{l}0.006 \\
(0.024)\end{array}$ & $\begin{array}{l}0.015 \\
(0.024)\end{array}$ \\
\hline Social activities & $\begin{array}{l}0.127^{\text {**** }} \\
(0.019)\end{array}$ & $\begin{array}{l}0.127^{* * * *} \\
(0.019)\end{array}$ & $\begin{array}{l}0.119 * * * \\
(0.019)\end{array}$ & $\begin{array}{l}0.124^{* * *} \\
(0.019)\end{array}$ \\
\hline Probability of leaving an inheritance greater than 50,000 euro & $\begin{array}{l}0.003^{* * *} \\
(0.000)\end{array}$ & $\begin{array}{l}0.003^{* * *} \\
(0.000)\end{array}$ & $\begin{array}{l}0.002^{* * *} \\
(0.000)\end{array}$ & $\begin{array}{l}0.002^{* * * *} \\
(0.000)\end{array}$ \\
\hline Household income (in 100,000 euro) & $\begin{array}{l}0.009^{* *} \\
(0.006)\end{array}$ & $\begin{array}{l}0.008^{* *} \\
(0.004)\end{array}$ & $\begin{array}{l}0.008^{* *} \\
(0.004)\end{array}$ & $\begin{array}{l}0.008^{* *} \\
(0.005)\end{array}$ \\
\hline Real assets (in 100,000 euro) & $\begin{array}{l}0.003^{* * * *} \\
(0.001)\end{array}$ & $\begin{array}{l}0.003^{* * *} \\
(0.001)\end{array}$ & $\begin{array}{l}0.003^{* * * *} \\
(0.001)\end{array}$ & $\begin{array}{l}0.003^{* * *} \\
(0.001)\end{array}$ \\
\hline Household financial assets (in 100,000 euro) & $\begin{array}{l}0.063^{* * * *} \\
(0.013)\end{array}$ & $\begin{array}{l}0.063^{* * *} \\
(0.013)\end{array}$ & $\begin{array}{l}0.062^{\text {**** }} \\
(0.013)\end{array}$ & $\begin{array}{l}0.063^{* * *} \\
(0.013)\end{array}$ \\
\hline Pseudo $\mathrm{R}^{2}$ & 0.211 & 0.211 & 0.213 & 0.211 \\
\hline Observations & 18,402 & 18,402 & 18,402 & 18,413 \\
\hline
\end{tabular}

Same as in Table 6.

specific features. The fields we are studying in our paper might be indeed highly affected by country characteristics, not only in terms of healthcare organization, but also concerning the financial system and the development of personal finance opportunities.

Finally, in order to further explore the "precautionary saving motive" as a potential channel of health risk transmission, we consider the payment at the household level of out-of-pocket (OOP) medical expenditures, as done in Rosen and Wu (2004). OOP include non-refunded expenses for inpatient care, outpatient care, prescribed drugs and nursing homes sustained in the previous 12 months, with monetary values expressed in euros and adjusted by the purchasing power parity. Augmenting the basic models with OOP medical expenditures does not alter the main result, since the health effect is in most of the cases negative, and self-reported health has larger negative explanatory power, while the variable for OOP expenses is never significant, revealing that OOP medical expenditures do not strongly influence portfolio choice (see Table 13).

\section{Risk aversion and health conditions}

On the basis of the analysis presented so far, while we can exclude the hypothesis of the shortening of the life time horizon, it is quite difficult to disentangle the other two potential channels of health risk transmission, namely the precautionary saving motive and the direct effect on the marginal utility of consumption (pure risk aversion). Both channels of risk transmission are likely to affect jointly portfolio choices. As a final test of our analysis, we explore whether the health condition of our respondents affects their risk perception. We refer to one question contained in SHARE which should convey information on the attitude of respondents towards financial risk. ${ }^{2}$

We construct a dichotomous variable assuming value one if the respondent has a high risk aversion, while zero if the respondent has a low risk aversion. In Table 14 the dependent variable is the risk aversion dummy, while the explanatory set is the same as in the baseline regressions.

The marginal effect from the health proxies is positive (except for $A D L$ ), but very low, and only EUROD is statistically significant. Bad health conditions might modify risk preferences towards a lower willingness to take financial risk, although our data would not significantly support this statement. The current health status is not a primary driver in determining the level of risk undertaken during investments. From the set of controls, we see how better education, more social activities and good numeracy ability might render investors more inclined to assume financial risk. Finally, we also check whether the attitude towards risk is affecting the asset allocation. In Table 15 we see the impact from the proxy for risk aversion on the portfolio choice. As expected, risk averse individuals are less willing to invest in equity or other "riskier" investments, and among the health proxies, is again SPHEU the only variable with statistical relevance.

\footnotetext{
2 We consider one question, included in SHARE wave 2. It asks respondents "Which of the following statements comes closest to the amount of financial risk that you are willing to take when you save or make investments? 1. Take substantial financial risks expecting to earn substantial returns; 2 . Take above average financial risks expecting to earn above average returns; 3 . Take average financial risks expecting to earn average returns; 4 . Not willing to take any financial risks". We have generated a dummy variable for risk aversion equal to one if the respondent is not willing to take any financial risks.
} 
Table 7

Regressions for stockholding (direct and total) and risky investment.

\begin{tabular}{|c|c|c|c|}
\hline & Direct stockholding & Total stockholding & Risky investment \\
\hline Variables & All health variables & All health variables & All health variables \\
\hline Number of limitations in activities of daily life (ADL) & $\begin{array}{l}0.002 \\
(0.005)\end{array}$ & $\begin{array}{l}0.007 \\
(0.009)\end{array}$ & $\begin{array}{l}0.012 \\
(0.017)\end{array}$ \\
\hline Number of chronic diseases (chronic) & $\begin{array}{c}-0.002 \\
(0.003)\end{array}$ & $\begin{array}{l}0.002 \\
(0.004)\end{array}$ & $\begin{array}{l}0.008 \\
(0.008)\end{array}$ \\
\hline Self-reported health (SPHEU) & $\begin{array}{l}-0.011^{* *} \\
(0.004)\end{array}$ & $\begin{array}{l}-0.036^{* * *} \\
(0.008)\end{array}$ & $\begin{array}{l}-0.066^{* * *} \\
(0.014)\end{array}$ \\
\hline Depression (EUROD) & $\begin{array}{l}-0.001 \\
(0.002)\end{array}$ & $\begin{array}{l}0.000 \\
(0.003)\end{array}$ & $\begin{array}{l}-0.006 \\
(0.005)\end{array}$ \\
\hline Age & $\begin{array}{l}0.003 \\
(0.004)\end{array}$ & $\begin{array}{l}0.013^{* *} \\
(0.006)\end{array}$ & $\begin{array}{l}0.014 \\
(0.011)\end{array}$ \\
\hline Age squared & $\begin{array}{c}-0.000 \\
(0.000)\end{array}$ & $\begin{array}{l}-0.000^{* * *} \\
(0.000)\end{array}$ & $\begin{array}{l}0.000^{*} \\
(0.000)\end{array}$ \\
\hline Number of household components & $\begin{array}{l}0.022^{* * *} \\
(0.005)\end{array}$ & $\begin{array}{l}0.033^{* * *} \\
(0.009)\end{array}$ & $\begin{array}{l}0.055^{* * *} \\
(0.016)\end{array}$ \\
\hline Education level & $\begin{array}{l}0.021^{* * *} \\
(0.002)\end{array}$ & $\begin{array}{l}0.035^{* * *} \\
(0.004)\end{array}$ & $\begin{array}{l}0.073^{* * *} \\
(0.007)\end{array}$ \\
\hline Numeracy & $\begin{array}{l}0.021^{* * * *} \\
(0.003)\end{array}$ & $\begin{array}{l}0.033^{* * *} \\
(0.006)\end{array}$ & $\begin{array}{l}0.063^{* * *} \\
(0.010)\end{array}$ \\
\hline Fluency & $\begin{array}{l}0.001^{* *} \\
(0.000)\end{array}$ & $\begin{array}{l}0.003^{* * *} \\
(0.001)\end{array}$ & $\begin{array}{l}0.006^{* * * *} \\
(0.001)\end{array}$ \\
\hline Recall & $\begin{array}{l}0.005^{* * *} \\
(0.002)\end{array}$ & $\begin{array}{l}0.006^{* *} \\
(0.003)\end{array}$ & $\begin{array}{l}0.011^{* *} \\
(0.005)\end{array}$ \\
\hline Employed & $\begin{array}{l}-0.002 \\
(0.008)\end{array}$ & $\begin{array}{l}0.004 \\
(0.013)\end{array}$ & $\begin{array}{l}0.006 \\
(0.024)\end{array}$ \\
\hline Social activities & $\begin{array}{l}0.025^{* * *} \\
(0.006)\end{array}$ & $\begin{array}{l}0.074^{* * *} \\
(0.012)\end{array}$ & $\begin{array}{l}0.118^{* * *} \\
(0.019)\end{array}$ \\
\hline Probability of leaving an inheritance greater than 50,000 euro & $\begin{array}{l}0.001^{* * *} \\
(0.000)\end{array}$ & $\begin{array}{l}0.001^{* * *} \\
(0.000)\end{array}$ & $\begin{array}{l}0.002^{* * * *} \\
(0.000)\end{array}$ \\
\hline $\begin{array}{l}\text { Household income } \\
\text { (in 100,000 euro) }\end{array}$ & $\begin{array}{l}0.004^{* *} \\
(0.002)\end{array}$ & $\begin{array}{l}0.008 \\
(0.006)\end{array}$ & $\begin{array}{l}0.008^{* *} \\
(0.004)\end{array}$ \\
\hline $\begin{array}{l}\text { Real assets } \\
\quad \text { (in } 100,000 \text { euro) }\end{array}$ & $\begin{array}{l}0.001^{* * *} \\
(0.000)\end{array}$ & $\begin{array}{l}0.002^{* * *} \\
(0.000)\end{array}$ & $\begin{array}{l}0.003^{* * *} \\
(0.001)\end{array}$ \\
\hline Household financial assets (in 100,000 euro) & $\begin{array}{l}0.027^{* * *} \\
(0.003)\end{array}$ & $\begin{array}{l}0.137^{* * * *} \\
(0.008)\end{array}$ & $\begin{array}{l}0.062^{* * *} \\
(0.013)\end{array}$ \\
\hline $\mathrm{R}^{2}$ & 0.223 & 0.300 & 0.213 \\
\hline Observations & 18,402 & 18,402 & 18,402 \\
\hline
\end{tabular}

Same as in Table 6 .

\section{Conclusion and discussion}

Using data from the Survey of Health, Aging and Retirement in Europe, we investigated the relationship between health conditions and portfolio choice for a large sample of people aged 50 and more. We inspected various profiles of human health using several proxies for the health condition: self-perceived health, objective health measured with the number of chronic conditions, and mental health proxied by the number of symptoms of depression. We find only a negative statistically relationship between self-perceived health and portfolio choices, suggesting that, the effect of poor health consists on making safer investment decisions. The results for other three measures of health are not statistically significant suggesting that they are not important for explaining investment decisions.

In general, our results are consistent with the theoretical underpinnings of background risk according to which a poor self-perceived health status, rather than the objective health condition, entails a higher risk of out-of-pocket medical expenditures, a higher risk of mortality, and yields households to reduce their exposure to financial risk. As Idler and Benyamini (1997) pointed out, self-perceived health is an independent predictor of mortality in nearly all of the studies examined, despite the inclusion of numerous specific health status indicators and other relevant covariates known to predict mortality.

There are several potential reasons why the three other measures of health status are not equally and significantly correlated with portfolio choices. Firstly, each of the three alternative measures reflect only one dimension of overall health status while the self-perceived health status collects all these information and provides an overall evaluation of health. Self-perceived health captures the full array of illness a person has, and possibly even symptoms of disease. Secondly, self-perceived health represents complex human judgments about the severity of current illness. With the exception of Atella et al. (2012), most of the studies considering measures of objective health did not weight the illness in any way. However, it is clear that the severity of illness varies over time and between individuals. This differential weighting might be better captured by perceived health rather than dichotomous diagnostic categories. Thirdly, measures of objective health do not capture the effect of comorbidity. Indeed, there may be complex interactions between conditions that are not captured by an additive measure of chronic diseases and that could be better captured by a comprehensive measure of health, i.e. the self-perceived health. Finally, as Idler and Kasl (1991) suggest, self-assessment of health reflects a personal estimate of longevity that may be based not only on knowledge of the respondent's own current health but also on the knowledge of familiar risk factors: " $\mathrm{A}$ family's vulnerability to specific diseases and pattern of longevity represents a social source of knowledge that grows as people age and experience the death of first grandparents and then parents" (Idler \& Kasl, 1991, page 28).

Our results are also consistent with most of the findings from previous contributions of the literature. Feinstein and Lin (2006), Edwards (2008), Love and Smith (2010), Cardak and Wilkins (2009) and Yogo (2012) use only self-reported health as a measure of health status and they find that a poor perceived health is negatively associated with stock market participation and with the share of risky investments in the portfolio. Atella et al. (2012) consider several measures of health: perceived health status, a measure of objective health, weighted according to the disease's degree of severity, and a generated measure to proxy future health risk (defined as a function of risky behavior, asymptomatic 
Table 8

The effect of subjective health on stockholding (direct and total) and risky investment, including an interaction between health and age.

\begin{tabular}{|c|c|c|c|}
\hline Variables & Direct stockholding & Total stockholding & Risky investment \\
\hline Number of limitations in activities of daily life (ADL) & $\begin{array}{l}0.0047 \\
(0.008)\end{array}$ & $\begin{array}{l}0.009 \\
(0.016)\end{array}$ & $\begin{array}{l}0.017 \\
(0.032)\end{array}$ \\
\hline Number of chronic diseases (chronic) & $\begin{array}{l}-0.002 \\
(0.004)\end{array}$ & $\begin{array}{l}0.005 \\
(0.007)\end{array}$ & $\begin{array}{l}0.008 \\
(0.012)\end{array}$ \\
\hline Self-reported health (SPHEU) & $\begin{array}{l}-0.011^{* *} \\
(0.006)\end{array}$ & $\begin{array}{l}-0.033^{* * *} \\
(0.010)\end{array}$ & $\begin{array}{l}-0.051^{* * *} \\
(0.018)\end{array}$ \\
\hline Depression (EUROD) & $\begin{array}{l}0.000 \\
(0.002)\end{array}$ & $\begin{array}{l}0.001 \\
(0.003)\end{array}$ & $\begin{array}{l}-0.003 \\
(0.006)\end{array}$ \\
\hline Aged 65+ & $\begin{array}{l}-.0109 \\
(0.019)\end{array}$ & $\begin{array}{l}0.003 \\
(0.034)\end{array}$ & $\begin{array}{l}0.060 \\
(0.060)\end{array}$ \\
\hline ADL * Aged 65+ & $\begin{array}{l}-0.005 \\
(0.011)\end{array}$ & $\begin{array}{c}-0.004 \\
(0.019)\end{array}$ & $\begin{array}{c}-0.006 \\
(0.039)\end{array}$ \\
\hline Chronic $*$ Aged $65+$ & $\begin{array}{l}0.000 \\
(0.005)\end{array}$ & $\begin{array}{c}-0.003 \\
(0.009)\end{array}$ & $\begin{array}{l}0.002 \\
(0.016)\end{array}$ \\
\hline SPHEU $*$ Aged $65+$ & $\begin{array}{l}0.002 \\
(0.008)\end{array}$ & $\begin{array}{c}-0.007 \\
(0.014)\end{array}$ & $\begin{array}{c}-0.035 \\
(0.026)\end{array}$ \\
\hline EUROD $*$ Aged 65 + & $\begin{array}{c}-0.002 \\
(0.003)\end{array}$ & $\begin{array}{l}-0.002 \\
(0.005)\end{array}$ & $\begin{array}{l}-0.007 \\
(0.009)\end{array}$ \\
\hline $\mathrm{R}^{2}$ & 0.223 & 0.300 & 0.214 \\
\hline Observations & 18,402 & 18,402 & 18,402 \\
\hline
\end{tabular}

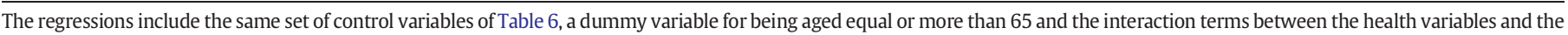
dummy variable for age $65+$.

Table 9

Regressions for stockholding and risky investment - interaction term between health and expected probability of dying in the next ten years.

\begin{tabular}{|c|c|c|c|}
\hline Variables & Direct stockholding & Total stockholding & Risky investment \\
\hline Number of limitations in activities of daily life (ADL) & $\begin{array}{c}-0.002 \\
(0.011)\end{array}$ & $\begin{array}{l}0.006 \\
(0.017)\end{array}$ & $\begin{array}{c}-0.013 \\
(0.032)\end{array}$ \\
\hline Number of chronic diseases (chronic) & $\begin{array}{c}-0.006 \\
(0.005)\end{array}$ & $\begin{array}{l}-0.004 \\
(0.008)\end{array}$ & $\begin{array}{c}-0.005 \\
(0.014)\end{array}$ \\
\hline Self-reported health (SPHEU) & $\begin{array}{l}-0.009 \\
(0.008)\end{array}$ & $\begin{array}{l}-0.027^{* *} \\
(0.014)\end{array}$ & $\begin{array}{l}-0.036 \\
(0.025)\end{array}$ \\
\hline Depression (EUROD) & $\begin{array}{l}0.002 \\
(0.003)\end{array}$ & $\begin{array}{l}0.005 \\
(0.005)\end{array}$ & $\begin{array}{l}0.004 \\
(0.008)\end{array}$ \\
\hline Pr. of dying within 10 years & $\begin{array}{l}0.000 \\
(0.000)\end{array}$ & $\begin{array}{l}0.001 \\
(0.001)\end{array}$ & $\begin{array}{l}0.002^{* *} \\
(0.001)\end{array}$ \\
\hline ADL $*$ pr. of dying within 10 years & $\begin{array}{l}0.000 \\
(0.000)\end{array}$ & $\begin{array}{l}0.000 \\
(0.000)\end{array}$ & $\begin{array}{l}0.000 \\
(0.001)\end{array}$ \\
\hline Chronic * pr. of dying within 10 years & $\begin{array}{l}0.000 \\
(0.000)\end{array}$ & $\begin{array}{l}0.000 \\
(0.000)\end{array}$ & $\begin{array}{l}0.000 \\
(0.000)\end{array}$ \\
\hline $\mathrm{SPHE} *$ pr. of dying within 10 years & $\begin{array}{c}-0.000 \\
(0.000)\end{array}$ & $\begin{array}{c}-0.000 \\
(0.000)\end{array}$ & $\begin{array}{l}-0.001^{* *} \\
(0.000)\end{array}$ \\
\hline EUROD $*$ pr. of dying within 10 years & $\begin{array}{l}-0.000 \\
(0.000)\end{array}$ & $\begin{array}{c}-0.000 \\
(0.000)\end{array}$ & $\begin{array}{l}-0.000 \\
(0.000)\end{array}$ \\
\hline $\mathrm{R}^{2}$ & 0.221 & 0.299 & 0.216 \\
\hline Observations & 17,593 & 17,593 & 17,593 \\
\hline
\end{tabular}

Same as Table 10

Table 10

Regressions for stockholding and risky investment - ownership of private health insurance.

\begin{tabular}{|c|c|c|c|}
\hline Variables & Direct stockholding & Total stockholding & Risky investment \\
\hline Number of limitations in activities of daily life (ADL) & $\begin{array}{l}-0.002 \\
(0.003)\end{array}$ & $\begin{array}{l}-0.006 \\
(0.005)\end{array}$ & $\begin{array}{l}-0.017^{*} \\
(0.010)\end{array}$ \\
\hline Number of chronic diseases (chronic) & $\begin{array}{l}-0.006^{*} \\
(0.003)\end{array}$ & $\begin{array}{l}-0.010^{\text {** }} \\
(0.005)\end{array}$ & $\begin{array}{l}-0.017^{* *} \\
(0.009)\end{array}$ \\
\hline Self-reported health (SPHEU) & $\begin{array}{l}-0.006^{* *} \\
(0.003)\end{array}$ & $\begin{array}{l}-0.025^{* * *} \\
(0.005)\end{array}$ & $\begin{array}{l}-0.053^{* * *} \\
(0.009)\end{array}$ \\
\hline Depression (EUROD) & $\begin{array}{c}-0.002 \\
(0.003)\end{array}$ & $\begin{array}{l}-0.002 \\
(0.005)\end{array}$ & $\begin{array}{l}-0.015^{*} \\
(0.009)\end{array}$ \\
\hline Health insured & $\begin{array}{l}0.038^{* * * *} \\
(0.008)\end{array}$ & $\begin{array}{l}0.077^{* * *} \\
(0.013)\end{array}$ & $\begin{array}{l}0.156^{* * *} \\
(0.022)\end{array}$ \\
\hline $\mathrm{R}^{2}$ & 0.225 & 0.306 & 0.220 \\
\hline Observations & 19,436 & 19,436 & 19,436 \\
\hline
\end{tabular}

Same as Table 10 
Table 11

Regressions for stockholding and risky investment - interaction terms between health status and health insurance.

\begin{tabular}{|c|c|c|c|}
\hline Variables & Direct stockholding & Total stockholding & Risky investment \\
\hline $\begin{array}{l}\text { Number of limitations in activities of daily life } \\
\text { (ADL) }\end{array}$ & $\begin{array}{l}-0.001 \\
(0.006)\end{array}$ & $\begin{array}{l}0.003 \\
(0.010)\end{array}$ & $\begin{array}{l}-0.001 \\
(0.020)\end{array}$ \\
\hline Number of chronic diseases (chronic) & $\begin{array}{l}0.002 \\
(0.003)\end{array}$ & $\begin{array}{l}0.006 \\
(0.005)\end{array}$ & $\begin{array}{l}0.015 \\
(0.009)\end{array}$ \\
\hline Self-reported health (SPHEU) & $\begin{array}{l}-0.015^{* * *} \\
(0.005)\end{array}$ & $\begin{array}{l}-0.045^{* * *} \\
(0.008)\end{array}$ & $\begin{array}{l}-0.088^{* * *} \\
(0.015)\end{array}$ \\
\hline Depression (EUROD) & $\begin{array}{l}0.001 \\
(0.002)\end{array}$ & $\begin{array}{l}-0.001 \\
(0.003)\end{array}$ & $\begin{array}{l}-0.006 \\
(0.006)\end{array}$ \\
\hline Health insured & $\begin{array}{l}0.016 \\
(0.016)\end{array}$ & $\begin{array}{l}0.022 \\
(0.027)\end{array}$ & $\begin{array}{l}0.053 \\
(0.046)\end{array}$ \\
\hline ADL $*$ health insured & $\begin{array}{l}0.009 \\
(0.010)\end{array}$ & $\begin{array}{l}0.010 \\
(0.016)\end{array}$ & $\begin{array}{l}0.023 \\
(0.029)\end{array}$ \\
\hline chronic $*$ health insured & $\begin{array}{l}-0.008^{*} \\
(0.004)\end{array}$ & $\begin{array}{l}-0.011 \\
(0.007)\end{array}$ & $\begin{array}{l}-0.014 \\
(0.013)\end{array}$ \\
\hline SPHEU $*$ health insured & $\begin{array}{l}0.017 * * \\
(0.007)\end{array}$ & $\begin{array}{l}0.029^{* *} \\
(0.012)\end{array}$ & $\begin{array}{l}0.056^{* *} \\
(0.023)\end{array}$ \\
\hline EUROD $*$ health insured & $\begin{array}{l}-0.004 \\
(0.003)\end{array}$ & $\begin{array}{l}0.001 \\
(0.005)\end{array}$ & $\begin{array}{c}-0.002 \\
(0.008)\end{array}$ \\
\hline $\mathrm{R}^{2}$ & 0.225 & 0.306 & 0.221 \\
\hline Observations & 19,436 & 19,436 & 19,436 \\
\hline
\end{tabular}

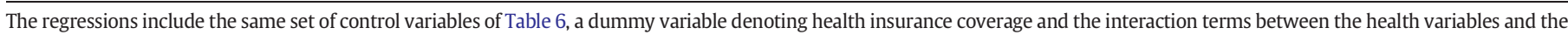
dummy variable for health insurance coverage.

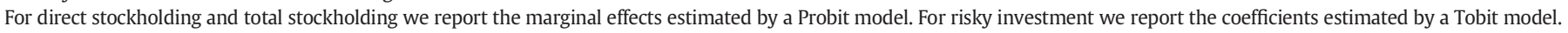
Significance: ${ }^{*} 10 \%,{ }^{* *} 5 \%,{ }^{* * *} 1 \%$ confidence levels.

objective health and grip strength). They discover that the household's decision to hold risky assets is driven primarily by the perceived health status rather than by the objective health condition. Poterba, Venti, and Wise (2011) consider a simple measure of health status based on the first principal component of Health and Retirement Survey responses on self-reported health status, diagnoses, activities of daily living, instrumental activities of daily living, and other indicators of underlying health. They find that persons in the top third of the health distribution accumulate at least $50 \%$ more assets than persons in the bottom third of the health distribution. However, their health measure is rather comprehensive and we cannot make a direct comparison of these results with ours.

To the best of our knowledge, only Rosen and Wu (2004) and Coile and Milligan (2009) provide results slightly in contrast with our findings. The first paper associates the health condition to specific medical diagnoses and to an index of the individual's ability to conduct activities of daily living, besides the self-perceived health. They show that all these measures of health are associated with a smaller share of financial wealth held in risky assets in favor of a larger share held in safe assets. The second paper does not use self-perceived health as a

Table 12

Regressions for stockholding and risky investment - by public health system.

\begin{tabular}{|c|c|c|c|c|c|c|}
\hline \multirow[b]{2}{*}{ Variables } & \multicolumn{2}{|c|}{ Direct stockholding } & \multicolumn{2}{|c|}{ Total stockholding } & \multicolumn{2}{|c|}{ Risky investment } \\
\hline & NHS countries & Non-NHS countries & NHS countries & Non-NHS countries & NHS countries & Non-NHS countries \\
\hline Number of limitations in activities of daily life (ADL) & $\begin{array}{l}0.002 \\
(0.006)\end{array}$ & $\begin{array}{l}-0.002 \\
(0.009)\end{array}$ & $\begin{array}{l}0.007 \\
(0.010)\end{array}$ & $\begin{array}{l}0.003 \\
(0.017)\end{array}$ & $\begin{array}{l}0.014 \\
(0.025)\end{array}$ & $\begin{array}{l}-0.002 \\
(0.031)\end{array}$ \\
\hline Number of chronic diseases (chronic) & $\begin{array}{l}0.003 \\
(0.003)\end{array}$ & $\begin{array}{l}0.001 \\
(0.005)\end{array}$ & $\begin{array}{l}0.005 \\
(0.005)\end{array}$ & $\begin{array}{l}0.012 \\
(0.008)\end{array}$ & $\begin{array}{l}0.025^{*} \\
(0.014)\end{array}$ & $\begin{array}{l}0.012 \\
(0.012)\end{array}$ \\
\hline Self-reported health (SPHEU) & $\begin{array}{l}-0.012^{* *} \\
(0.005)\end{array}$ & $\begin{array}{l}-0.020^{* *} \\
(0.009)\end{array}$ & $\begin{array}{l}-0.030^{* * *} \\
(0.008)\end{array}$ & $\begin{array}{l}-0.061^{* * *} \\
(0.015)\end{array}$ & $\begin{array}{l}-0.089^{* * *} \\
(0.022)\end{array}$ & $\begin{array}{l}-0.092^{* * *} \\
(0.022)\end{array}$ \\
\hline Depression (EUROD) & $\begin{array}{l}-0.002 \\
(0.002)\end{array}$ & $\begin{array}{l}0.004 \\
(0.003)\end{array}$ & $\begin{array}{l}-0.004 \\
(0.003)\end{array}$ & $\begin{array}{l}0.004 \\
(0.006)\end{array}$ & $\begin{array}{l}-0.015^{*} \\
(0.008)\end{array}$ & $\begin{array}{l}-0.000 \\
(0.008)\end{array}$ \\
\hline Health insured & $\begin{array}{l}-0.010 \\
(0.021)\end{array}$ & $\begin{array}{l}0.009 \\
(.023)\end{array}$ & $\begin{array}{l}0.133^{* *} \\
(0.066)\end{array}$ & $\begin{array}{l}-0.014 \\
(0.038)\end{array}$ & $\begin{array}{l}0.121 \\
(0.096)\end{array}$ & $\begin{array}{l}0.027 \\
(0.057)\end{array}$ \\
\hline $\mathrm{ADL} *$ health insured & $\begin{array}{c}-0.013 \\
(0.018)\end{array}$ & $\begin{array}{l}0.013 \\
(0.013)\end{array}$ & $\begin{array}{l}-0.032 \\
(0.032)\end{array}$ & $\begin{array}{l}0.010 \\
(0.022)\end{array}$ & $\begin{array}{l}-0.064 \\
(0.078)\end{array}$ & $\begin{array}{l}0.023 \\
(0.038)\end{array}$ \\
\hline Chronic $*$ health insured & $\begin{array}{l}0.002 \\
(0.007)\end{array}$ & $\begin{array}{l}-0.009 \\
(0.006)\end{array}$ & $\begin{array}{l}-0.006 \\
(0.016)\end{array}$ & $\begin{array}{l}-0.018^{*} \\
(0.010)\end{array}$ & $\begin{array}{l}-0.012 \\
(0.039)\end{array}$ & $\begin{array}{l}-0.016 \\
(0.016)\end{array}$ \\
\hline SPHEU $*$ health insured & $\begin{array}{l}0.013 \\
(0.012)\end{array}$ & $\begin{array}{l}0.025^{* *} \\
(0.011)\end{array}$ & $\begin{array}{l}-0.004 \\
(0.023)\end{array}$ & $\begin{array}{l}0.047^{* *} \\
(0.018)\end{array}$ & $\begin{array}{l}0.044 \\
(0.048)\end{array}$ & $\begin{array}{l}0.057^{* *} \\
(0.028)\end{array}$ \\
\hline EUROD $*$ health insured & $\begin{array}{l}0.002 \\
(0.005)\end{array}$ & $\begin{array}{l}-0.008^{*} \\
(0.004)\end{array}$ & $\begin{array}{c}-0.001 \\
(0.009)\end{array}$ & $\begin{array}{c}-0.002 \\
(0.007)\end{array}$ & $\begin{array}{l}0.003 \\
(0.023)\end{array}$ & $\begin{array}{l}-0.005 \\
(0.010)\end{array}$ \\
\hline $\mathrm{R}^{2}$ & 0.235 & 0.236 & 0.340 & 0.279 & 0.247 & 0.210 \\
\hline Observations & 6955 & 12,481 & 6955 & 12,481 & 6955 & 12,481 \\
\hline
\end{tabular}

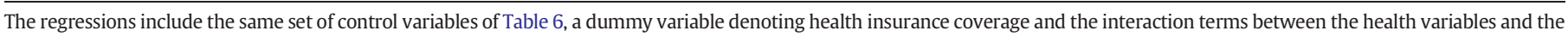
dummy variable for health insurance coverage.

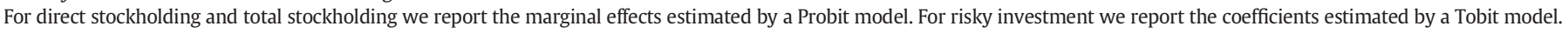
Significance: ${ }^{*} 10 \%,{ }^{*} 5 \%$, ${ }^{* * *} 1 \%$ confidence levels.

NHS countries and Non-NHS countries are classified as in Atella et al. (2012). 
Table 13

The effect of health on stockholding and on risky investment, including out-of-pocket medical expenses.

\begin{tabular}{|c|c|c|c|c|c|c|}
\hline \multirow[t]{2}{*}{ Variables } & \multicolumn{2}{|c|}{ Direct stockholding } & \multicolumn{2}{|c|}{ Total stockholding } & \multicolumn{2}{|c|}{ Risky investment } \\
\hline & (a) & (b) & (a) & (b) & (a) & (b) \\
\hline Number of limitations in activities of daily life (ADL) & $\begin{array}{l}0.001 \\
(0.005)\end{array}$ & $\begin{array}{l}0.002 \\
(0.006)\end{array}$ & $\begin{array}{l}0.006 \\
(0.009)\end{array}$ & $\begin{array}{l}0.005 \\
(0.010)\end{array}$ & $\begin{array}{l}0.010 \\
(0.017)\end{array}$ & $\begin{array}{l}0.008 \\
(0.019)\end{array}$ \\
\hline Number of chronic diseases (chronic) & $\begin{array}{l}-0.003 \\
(0.003)\end{array}$ & $\begin{array}{l}-0.001 \\
(0.003)\end{array}$ & $\begin{array}{l}0.002 \\
(0.004)\end{array}$ & $\begin{array}{l}0.006 \\
(0.005)\end{array}$ & $\begin{array}{l}0.008 \\
(0.008)\end{array}$ & $\begin{array}{l}0.014 \\
(0.008)\end{array}$ \\
\hline Self-reported health (SPHEU) & $\begin{array}{l}-0.011^{* *} \\
(0.004)\end{array}$ & $\begin{array}{l}-0.011^{* *} \\
(0.005)\end{array}$ & $\begin{array}{l}-0.036^{* * *} \\
(0.008)\end{array}$ & $\begin{array}{l}-0.037^{* * *} \\
(0.008)\end{array}$ & $\begin{array}{l}-0.067^{* * *} \\
(0.014)\end{array}$ & $\begin{array}{l}-0.067^{* * *} \\
(0.014)\end{array}$ \\
\hline Depression (EUROD) & $\begin{array}{l}-0.001 \\
(0.002)\end{array}$ & $\begin{array}{l}-0.001 \\
(0.002)\end{array}$ & $\begin{array}{l}0.000 \\
(0.003)\end{array}$ & $\begin{array}{l}0.000 \\
(0.003)\end{array}$ & $\begin{array}{l}-0.007 \\
(0.005)\end{array}$ & $\begin{array}{l}-0.007 \\
(0.005)\end{array}$ \\
\hline $\begin{array}{l}\text { OOP medical expenses } \\
\text { (in } 100 \text { euro) }\end{array}$ & $\begin{array}{l}0.000^{*} \\
(0.000)\end{array}$ & $\begin{array}{l}0.001 \\
(0.001)\end{array}$ & $\begin{array}{l}0.001 \\
(0.000)\end{array}$ & $\begin{array}{l}0.002 \\
(0.002)\end{array}$ & $\begin{array}{l}0.001 \\
(0.001)\end{array}$ & $\begin{array}{l}0.004 \\
(0.003)\end{array}$ \\
\hline $\mathrm{ADL} *$ OOP medical expenses & & $\begin{array}{l}0.000 \\
(0.000)\end{array}$ & & $\begin{array}{l}0.000 \\
(0.000)\end{array}$ & & $\begin{array}{l}0.000 \\
(0.001)\end{array}$ \\
\hline Chronic $*$ OOP medical expenses & & $\begin{array}{l}-0.000 \\
(0.000)\end{array}$ & & $\begin{array}{l}-0.001^{\text {**** }} \\
(0.000)\end{array}$ & & $\begin{array}{l}-0.002^{* *} \\
(0.001)\end{array}$ \\
\hline SPHEU $*$ OOP medical expenses & & $\begin{array}{l}-0.000 \\
(0.000)\end{array}$ & & $\begin{array}{l}0.000 \\
(0.000)\end{array}$ & & $\begin{array}{l}-0.000 \\
(0.001)\end{array}$ \\
\hline EUROD $*$ OOP medical expenses & & $\begin{array}{l}0.000 \\
(0.000)\end{array}$ & & $\begin{array}{l}0.000 \\
(0.000)\end{array}$ & & $\begin{array}{l}0.000 \\
(0.000)\end{array}$ \\
\hline $\mathrm{R}^{2}$ & 0.223 & 0.224 & 0.300 & 0.301 & 0.213 & 0.214 \\
\hline Observations & 18,402 & 18,402 & 18,402 & 18,402 & 18,402 & 18,402 \\
\hline
\end{tabular}

The regressions include the same set of control variables of Table 6.

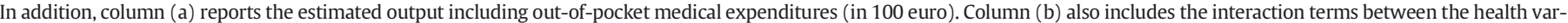
iables and out-of-pocket medical expenditures.

Table 14

Regression for risk aversion.

\begin{tabular}{|c|c|}
\hline & Risk aversion (dummy variable) \\
\hline Variables & $\mathrm{dy} / \mathrm{dx}$ \\
\hline Number of limitations in activities of daily life (ADL) & $\begin{array}{l}-0.004 \\
(0.009)\end{array}$ \\
\hline Number of chronic diseases (chronic) & $\begin{array}{l}0.006 \\
(0.004)\end{array}$ \\
\hline Self-reported health (SPHEU) & $\begin{array}{l}0.011 \\
(0.007)\end{array}$ \\
\hline Depression (EUROD) & $\begin{array}{l}0.006^{* *} \\
(0.003)\end{array}$ \\
\hline Age & $\begin{array}{l}-0.011 \\
(0.007)\end{array}$ \\
\hline Age squared & $\begin{array}{l}-0.000^{*} \\
(0.000)\end{array}$ \\
\hline Number of household components & $\begin{array}{l}-0.030^{* * *} \\
(0.009)\end{array}$ \\
\hline Education level & $\begin{array}{l}-0.030^{* * *} \\
(0.004)\end{array}$ \\
\hline Numeracy & $\begin{array}{l}-0.021^{* * *} \\
(0.006)\end{array}$ \\
\hline Fluency & $\begin{array}{l}-0.002^{*} \\
(0.001)\end{array}$ \\
\hline Recall & $\begin{array}{l}-0.002 \\
(0.003)\end{array}$ \\
\hline Employed & $\begin{array}{l}-0.021 \\
(0.014)\end{array}$ \\
\hline Social activities & $\begin{array}{l}-0.049^{* * *} \\
(0.010)\end{array}$ \\
\hline Probability of leaving an inheritance greater than 50,000 euro & $\begin{array}{l}-0.001^{* * *} \\
(0.000)\end{array}$ \\
\hline Household income (in 100,000 euro) & $\begin{array}{l}0.000 \\
(0.000)\end{array}$ \\
\hline Real assets (in 100,000 euro) & $\begin{array}{l}-0.000^{* * *} \\
(0.000)\end{array}$ \\
\hline Household financial assets (in 100,000 euro) & $\begin{array}{l}-0.002^{* * *} \\
(0.000)\end{array}$ \\
\hline $\mathrm{R}^{2}$ & 0.149 \\
\hline Observations & 12,345 \\
\hline
\end{tabular}

Estimation is performed on individuals classified as "financial respondents".

Significance: ${ }^{*} 10 \%,{ }^{* *} 5 \%,{ }^{* * *} 1 \%$ confidence levels. 
Table 15

Regressions for stockholding and risky investment, controlling for risk aversion.

\begin{tabular}{|c|c|c|c|}
\hline Variables & Direct stockholding & Total stockholding & Risky investment \\
\hline Number of limitations in activities of daily life (ADL) & $\begin{array}{l}0.000 \\
(0.006)\end{array}$ & $\begin{array}{l}0.006 \\
(0.012)\end{array}$ & $\begin{array}{l}0.020 \\
(0.025)\end{array}$ \\
\hline Number of chronic diseases (chronic) & $\begin{array}{l}0.000 \\
(0.003)\end{array}$ & $\begin{array}{l}0.001 \\
(0.005)\end{array}$ & $\begin{array}{l}0.006 \\
(0.009)\end{array}$ \\
\hline Self-reported health (SPHEU) & $\begin{array}{l}-0.010^{* *} \\
(0.005)\end{array}$ & $\begin{array}{l}-0.027^{* * *} \\
(0.009)\end{array}$ & $\begin{array}{l}-0.050^{* * *} \\
(0.016)\end{array}$ \\
\hline Depression (EUROD) & $\begin{array}{l}-0.001 \\
(0.002)\end{array}$ & $\begin{array}{l}-0.001 \\
(0.003)\end{array}$ & $\begin{array}{l}-0.005 \\
(0.006)\end{array}$ \\
\hline Risk aversion (dummy variable) & $\begin{array}{l}-0.090^{* * * *} \\
(0.011)\end{array}$ & $\begin{array}{l}-0.176^{* * *} \\
(0.018)\end{array}$ & $\begin{array}{l}-0.265^{* * *} \\
(0.025)\end{array}$ \\
\hline Age & $\begin{array}{l}-0.002 \\
(0.005)\end{array}$ & $\begin{array}{l}0.004 \\
(0.009)\end{array}$ & $\begin{array}{l}0.016 \\
(0.015)\end{array}$ \\
\hline Age squared & $\begin{array}{l}0.000 \\
(0.000)\end{array}$ & $\begin{array}{l}-0.000 \\
(0.000)\end{array}$ & $\begin{array}{l}0.000 \\
(0.000)\end{array}$ \\
\hline Number of household components & $\begin{array}{l}0.013^{* *} \\
(0.007)\end{array}$ & $\begin{array}{l}0.014 \\
(0.012)\end{array}$ & $\begin{array}{l}-0.075^{* * *} \\
(0.021)\end{array}$ \\
\hline Education level & $\begin{array}{l}0.013^{* * *} \\
(0.003)\end{array}$ & $\begin{array}{l}0.027^{* * * *} \\
(0.005)\end{array}$ & $\begin{array}{l}0.052^{* * * *} \\
(0.008)\end{array}$ \\
\hline Numeracy & $\begin{array}{l}0.013^{* * * *} \\
(0.004)\end{array}$ & $\begin{array}{l}0.022^{* * *} \\
(0.007)\end{array}$ & $\begin{array}{l}0.065^{* * *} \\
(0.012)\end{array}$ \\
\hline Fluency & $\begin{array}{l}0.001^{*} \\
(0.001)\end{array}$ & $\begin{array}{l}0.004^{* * * *} \\
(0.001)\end{array}$ & $\begin{array}{l}0.006^{* * *} \\
(0.002)\end{array}$ \\
\hline Recall & $\begin{array}{l}0.007^{* * *} \\
(0.002)\end{array}$ & $\begin{array}{l}0.010^{* * *} \\
(0.004)\end{array}$ & $\begin{array}{l}0.009 \\
(0.006)\end{array}$ \\
\hline Employed & $\begin{array}{c}-0.003 \\
(0.010)\end{array}$ & $\begin{array}{l}0.025 \\
(0.018)\end{array}$ & $\begin{array}{l}0.061^{* *} \\
(0.030)\end{array}$ \\
\hline Social activities & $\begin{array}{l}0.011 \\
(0.006)\end{array}$ & $\begin{array}{l}0.042^{* * * *} \\
(0.013)\end{array}$ & $\begin{array}{l}0.072^{* * *} \\
(0.020)\end{array}$ \\
\hline Probability of leaving an inheritance greater than 50,000 euro & $\begin{array}{l}0.001^{* * * *} \\
(0.000)\end{array}$ & $\begin{array}{l}0.001^{* * * *} \\
(0.000)\end{array}$ & $\begin{array}{l}0.003^{* * * *} \\
(0.000)\end{array}$ \\
\hline Household income (in 100,000 euro) & $\begin{array}{l}0.000^{* *} \\
(0.000)\end{array}$ & $\begin{array}{l}0.001 \\
(0.000)\end{array}$ & $\begin{array}{l}0.001 \\
(0.000)\end{array}$ \\
\hline Real assets (in 100,000 euro) & $\begin{array}{l}0.000^{* * * *} \\
(0.000)\end{array}$ & $\begin{array}{l}0.000^{*} \\
(0.000)\end{array}$ & $\begin{array}{l}0.000 \\
(0.000)\end{array}$ \\
\hline Household financial assets (in 100,000 euro) & $\begin{array}{l}0.003^{* * *} \\
(0.000)\end{array}$ & $\begin{array}{l}0.018^{* * *} \\
(0.003)\end{array}$ & $\begin{array}{l}0.005^{* * *} \\
(0.001)\end{array}$ \\
\hline $\mathrm{R}^{2}$ & 0.244 & 0.328 & 0.255 \\
\hline Observations & 12,345 & 12,345 & 12,345 \\
\hline
\end{tabular}

Estimation is performed on individuals classified as "financial respondents".

Significance: ${ }^{*} 10 \%,{ }^{* *} 5 \%$, ${ }^{* * *} 1 \%$ confidence levels.

measure of health status and focuses only on the influence of health shocks on the household's ownership of various assets, as well as on the dollar value and the share of total assets held in each asset class. The results suggest that the effect of acute events such as heart attack or stroke, or the effect of a newly diagnosed chronic illness reduces the probability of stocks and bonds holdings, while raises the share of assets held in bank accounts.

\section{References}

Ameriks, J., \& Zeldes, S. P. (2004). How do portfolio shares vary with age? : Mimeo, Columbia University.

Atella, V., Brunetti, M., \& Maestas, N. (2012). Household portfolio choices, health status and health care systems: A cross-country analysis based on SHARE. Journal of Banking \& Finance, 36, 1320-1335.

Berkowitz, M. K., \& Qiu, J. (2006). A further look at household portfolio choice and health status. Journal of Banking \& Finance, 30, 1201-1217.

Cardak, B.A., \& Wilkins, R. (2009). The determinants of household risky asset holdings: Australian evidence on background risk and other factors. Journal of Banking \& Finance, 33, 850-860.

Christelis, D., Jappelli, T., \& Padula, M. (2010). Cognitive abilities and portfolio choice. European Economic Review, 54, 18-38.

Coile, C., \& Milligan, K. (2009). How household portfolios evolve after retirement: the effect of aging and health shocks. Review of Income and Wealth, 55, 226-248.

Edwards, R. D. (2008). Health risk and portfolio choice. Journal of Business E Economic Statistics, 26, 472-485.

Edwards, R. D. (2010). Optimal portfolio choice when utility depends on health. International Journal of Economic Theory, 6, 205-225.

Feinstein, J. S., \& Lin, C. (2006). Elderly asset management. SSRN Working Paper 956399.

Finkelstein, A., Luttmer, E. F. P., \& Notowidigdo, M. J. (2008). What good is wealth without health? The Effect of Health on the Marginal Utility of Consumption. NBER Working Papers 14089.
Goldman, D. P., \& Maestas, N. A. (2007). Medical expenditure risk and household portfolio choice. RAND Working Paper N. 325-1.

Gollier, C. (2001). The economics of risk and time. Boston: MIT Press.

Gollier, C., \& Pratt, J. W. (1996). Risk vulnerability and the tempering effect of background risk. Econometrica, 64, 1109-1123.

Guiso, L., Jappelli, T., \& Terlizzese, D. (1996). Income risk, borrowing constraints, and portfolio choice. American Economic Review, 86, 158-172.

Guiso, L., \& Paiella, M. (2001). Risk aversion, wealth and background risk. Center for Economic Policy Research Discussion Paper.

Heaton, J., \& Lucas, D. (2000). Portfolio choice in the presence of background risk Economic Journal, 110, 1-26.

Hurd, M.D. (2002). Predictive validity of subjective probabilities of survival. Economic Journal, 112, 966-985.

Idler, E. L., \& Benyamini, Y. (1997). Self-rated health and mortality: A review of twenty-seven community studies. Journal of Health and Social Behavior, 38, 21-37.

Idler, E. L., \& Kasl, S. V. (1991). Health perceptions and survival: do global evaluations of health status really predict mortality? Journal of Gerontology: Social Sciences, 46, S55-S65.

Love, D. A., \& Smith, P. A. (2010). Does health affect portfolio choice. Health Economics, 19, 1441-1460.

Miniaci, R., \& Weber, G. (2002). Econometric issues in the estimation of household portfolio models. In Guido, Haliassos, \& Jappelli (Eds.), Household Portfolio. : The MIT Press.

Palumbo, M. G. (1999). Uncertain medical expenses and precautionary saving near the end of the life cycle. Review of Economic Studies, 66, 395-421.

Pang, G., \& Warshawsky, M. J. (2010). Optimizing the equity-bond-annuity portfolio in retirement: The impact of uncertain health expenses, "Insurance: Mathematics and Economics", 46. (pp. 198-209), 198-209.

Poterba, J. M., Venti, S. F., \& Wise, D. A. (2011). The asset cost of poor health. HKS Working Paper No. RWP 11-005.

Pratt, J. W., \& Zeckhauser, R. J. (1987). Proper risk aversion. Econometrica, 55, 143-154.

Rosen, H. S., \& Wu, S. (2004). Portfolio choice and health status. Journal of Financial Economics, 72, 457-484.

Smith, P. A. (1999). healthy bodies and thick wallets: The dual relationship between health and economic status. Journal of Economic Perspectives, 13, 145-166.

Yogo, M. (2012). Portfolio choice in retirement: Health risk and the demand for annuities, housing, and risky. Boston College Center for Retirement Research Working Paper No. 2009-3. 